\title{
Gedragsmechanismen achter overheidsinterventies en rechtsregels
}

Citation for published version (APA):

Leeuw, F. L. (2008). Gedragsmechanismen achter overheidsinterventies en rechtsregels. Océ. https://doi.org/10.26481/spe.20080523fl

Document status and date:

Published: 23/05/2008

DOI:

10.26481/spe.20080523fl

Document Version:

Publisher's PDF, also known as Version of record

\section{Please check the document version of this publication:}

- A submitted manuscript is the version of the article upon submission and before peer-review. There can be important differences between the submitted version and the official published version of record.

People interested in the research are advised to contact the author for the final version of the publication, or visit the DOI to the publisher's website.

- The final author version and the galley proof are versions of the publication after peer review.

- The final published version features the final layout of the paper including the volume, issue and page numbers.

Link to publication

\footnotetext{
General rights rights.

- You may freely distribute the URL identifying the publication in the public portal. please follow below link for the End User Agreement:

www.umlib.nl/taverne-license

Take down policy

If you believe that this document breaches copyright please contact us at:

repository@maastrichtuniversity.nl

providing details and we will investigate your claim.
}

Copyright and moral rights for the publications made accessible in the public portal are retained by the authors and/or other copyright owners and it is a condition of accessing publications that users recognise and abide by the legal requirements associated with these

- Users may download and print one copy of any publication from the public portal for the purpose of private study or research.

- You may not further distribute the material or use it for any profit-making activity or commercial gain

If the publication is distributed under the terms of Article $25 \mathrm{fa}$ of the Dutch Copyright Act, indicated by the "Taverne" license above, 
oratie

Universiteit Maastricht

\section{Frans L. Leeuw}

Gedragsmechanismen achter overheidsinterventies en rechtsregels
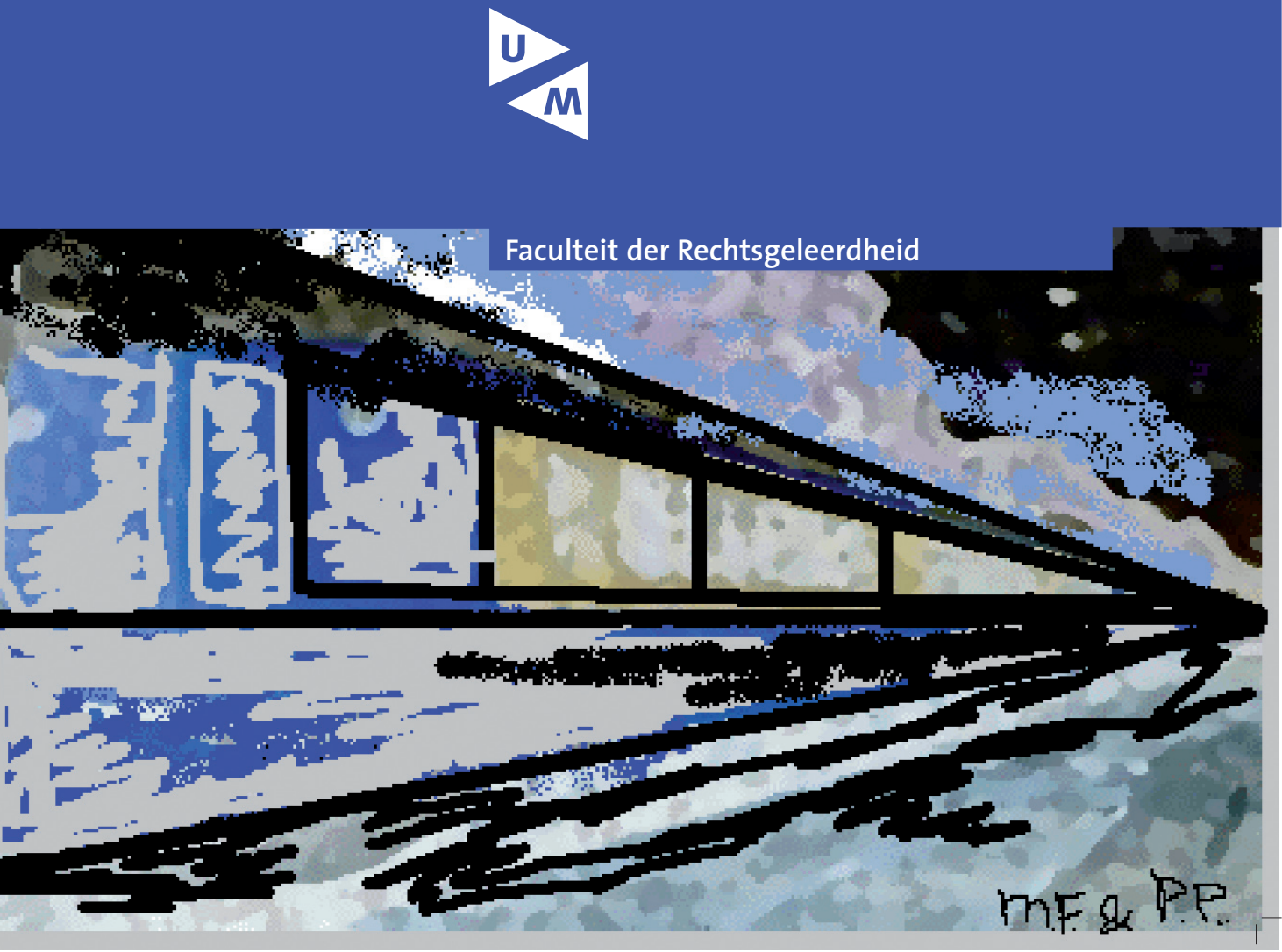

Gedragsmechanismen achter overheidsinterventies en rechtsregels 


\section{Colofon}

Ontwerp en print: Océ Business Services, Maastricht

ISBN: $\quad 978-90-5681-283-6$

NUR: $\quad 820$

Alle rechten voorbehouden. Niets uit deze uitgave mag worden verveelvoudigd, opgeslagen in een geautomatiseerd gegevensbestand of openbaar gemaakt worden, zonder voorafgaande schriftelijke toestemming van de auteur of uitgever. 


\title{
Gedragsmechanismen achter overheidsinterventies en rechtsregels
}

\begin{abstract}
Intreerede
In verkorte vorm uitgesproken bij de aanvaarding van het ambt van hoogleraar 'Recht, openbaar bestuur en sociaal-wetenschappelijk onderzoek' aan de Faculteit der Rechtsgeleerdheid van de Universiteit Maastricht.
\end{abstract}

Op vrijdag 23 mei 2008

door

Frans L. Leeuw

\section{Maastricht University}


'The complex, even in the human world, often finds its roots in the simple.'

M. Buchanan (2007)

'Policy-makers and practitioners are, like it or not, dealers in theory.'

N. Tilley (2008)

If I have described the judicial process accurately, the remaining question is what if anything should be done to improve it. Jerome Frank thought judges should undergo psychoanalysis, as he had done; this is a ridiculous suggestion. Professor Simon suggests techniques of debiasing, which sound a little ominous. I have a simpler suggestion. Since judges in our system are going to be legislators as well as adjudicators, they ought to take a greater interest in facts; and lawyers ought to make a greater effort to put the facts before them. I don't mean the facts of the case, the adjudicative facts. I mean the kind of background or general facts that influence a legislative decision.'

Richard A. Posner (2006)

Analysis of law should be linked with what we have been learning about human behaviour and choice.'

C.R. Sunstein (2000) 

Mijnheer de Rector, dames en heren

\section{Inleiding}

De Oosten rijkse econoom Ludwig von Mises publiceerde in 1929 zijn 'Kritik des Interventionismus'. In dit boek ontrafelde hij kenmerken van overheden die via bijvoorbeeld sociale politiek en belastingmaatregelen interveniëren in de samenleving. Hij formuleerde de theorie dat interventies van overheden tot onwenselijke resultaten leiden, met als gevolg de roep om steeds nieuwe interventies.

Vijftig jaar later, rond begin jaren tachtig, gaven Nederlandse maatschappijwetenschappers boekjes uit over wat heette de interventiestaat. ${ }^{3}$ Oud-Maastrichtenaar en socioloog Van Doorn, maar ook Schuyt en Peper gingen in op de vraag hoe het kwam dat de interventiestaat te maken had met een beperkte effectiviteit en aanzienlijke kosten. De mannenbroeders speurden naar condities hoe het interventionisme zo vorm te geven, dat het zou bijdragen aan vergroting van welzijn en welvaart van ingezetenen en tegelijkertijd geen 'effects pervers' zou veroorzaken. Aan de theorie van Von Mises werd niet gerefereerd, dit ondanks het feit dat een nieuwe druk van zijn 'Kritik des Interventionismus' een paar jaar eerder, in 1976, was verschenen. ${ }^{4}$ Meer in het algemeen werd in die jaren door sociaalwetenschappelijke denkers over de verzorgingsstaat vrij zelden naar werk van economen gekeken.5 Dat gold bijvoorbeeld ook voor studies van Hayek, ${ }^{6}$ toch niet de minste onder hen.7

Verkokering van kennis tussen vakgebieden is het woord dat hier past. Vooruitlopend op wat ik later met $u$ wil bespreken, is één van de doelen die ik nastreef met de Maastrichtse leerstoel 'Recht, openbaar bestuur en sociaal-wetenschappelijk onderzoek', bij te dragen aan reductie van verkokering. Daarover echter straks meer.

Er is een tweede reden dat ik $u$ mee terug neem in de tijd. Immers, de maatschappijwetenschappers die zo'n dertig jaar geleden op het interventionisme studeerden, deden dat niet in een sociaal of bestuurlijk luchtledige. Zij studeerden in een tijd dat de Nederlandse rijksoverheid ${ }^{8}$ begon aan een reis, die beoogde uit te komen bij minder interventies, minder regulering en meer effectiviteit. Zo startte het kabinet-Lubbers I de eerste dereguleringsronde, ${ }^{9}$ niet lang daarna gevolgd door de eerste privatisering- en verzelfstandigingronde, waraan ook in de MDWoperatie (marktwerking, deregulering en wetgevingskwaliteit) tussen 1994 en 2002 intensief aandacht werd besteed. Gepleit werd voor het 
drastisch verminderen van het aantal regels, wetten en 'beleiden' (Van Gestel \& Hertogh, 2006; Bokhorst \& Van Ommeren, 2007). Later, rond de jaren negentig, groeide het besef dat zelfregulering een alternatief kon zijn voor wet- en regelgeving, en weer een fase later, begin $21 e$ eeuw, kwam het door oud-minister van Justitie Donner geoormerkte begrip 'bruikbare rechtsorde' op de agenda. De filosofie daarachter leek te zijn de burger meer in staat te stellen zelf keuzes te maken, ook bij geschilbeslechting, om langs die weg te voorkomen dat de rechtsstaat bezwijkt aan regeldruk. Ruimtescheppende wetgeving, het beter gebruikmaken van bestaande wetgeving en het denken aan andere ordeningsmechanismen dan alleen wet- en regelgeving (zoals netwerken en sturen op sociaal kapitaal) zijn kernwoorden (Croes, 2007). Ook het kabinet-Balkenende IV gaf in de regeringsverklaring uit begin 2007 aan te streven naar minder bestuurlijke drukte, iets wat tot uitdrukking moest komen in minder regels, minder lastendruk, minder ambtenaren en minder organisaties. ${ }^{10}$

\section{Vraagstelling: Hoeveel Interventionisme in Nederland?}

Alhoewel het reflecteren op de interventiestaat in Nederland dus al enkele decennia op de politieke agenda staat en er ook flinke (institutionele) ingrepen in dit arrangement plaatsvonden, is het de vraag wat anno nu over het volume aan wet- en regelgeving en andere beleidsinterventies te zeggen is. Die vraag is niet alleen relevant omdat 'interventions breed interventions'", maar ook omdat evaluatieonderzoek frequent laat zien dat interventies en wetten niet doeltreffend zijn. Wellicht hangt dat samen met iets dat Bertolt Brecht lang geleden dichtte.

Ja, Mach mal einen Plan,

sei nur ein grosses Licht

und Mach dann noch'nen zweiten Plan,

gehen tun die beide nicht.'12

Laat ik, niet weerhouden door dit cynische perspectief, nagaan wat een weinig tel- en rekenwerk ten aanzien van interventies en regels oplevert.13

\section{Wet- en Regelgeving: Aard en Omvang}

Ik begin met wetten omdat daar belangrijke sturende vermogens aan toegeschreven worden. ${ }^{14}$ Koopmans (1970) maakte bijna veertig 
jaar geleden het treffende onderscheid tussen wetten die codificeren, modificeren en mobiliseren. Er is sprake van codificatie wanneer een wet gericht is 'op het juridisch vorm geven aan een of meer vaststaande normen' (Koopmans, 1970, p. 14). Als de wet een werktuig [wordt] om aan een gewenste verandering vorm te geven, is sprake van modificatie en als deze beleidsvormende functie meer en meer over gaat in beleidsuitvoering en bevoegdheidsverlening, is sprake van mobilisatie. Ook sprak Koopmans over de 'richtingbepalende functie' van wetgeving ( $p .3)$ en zag hij de moderne verzorgingsstaat goeddeels als de schepping van de wetgever (p. 2). Naast deze functies hebben wetten ook een waarborgfunctie. Waarborgen krijgen vaak vorm in (procedurele) eisen, zoals de zorgvuldige afweging van in het geding zijnde belangen, de bescherming van de privacy van het individu en de gelijke behandeling van mannen en vrouwen (Klein Haarhuis \& Niemeijer, 2008). In de praktijk zijn wetten overigens meestal een mengvorm van codificerende, modificerende en mobiliserende elementen (Veerman, 2007b).

Hoe zit het nu met de aantallen wetten die in ons land vigeren?

Ik baseer me deels op rekenwerk van De Jong en Herweijer (2004), die een paar jaar geleden in opdracht van het WODC het rapport 'Alle regels tellen' opstelden.

Op 1 januari 2007 golden er in Nederland op rijksniveau 1785 formele wetten. Daarnaast waren 2489 algemene maatregelen van bestuur (AMvB's) en koninklijke besluiten (KB's) en 6402 ministeriële regelingen van kracht. Het totale aantal formele wetten in Nederland is sinds 1980 met 685 toegenomen. De jaarlijkse groei is daarmee iets meer dan 2,2\% per jaar, redelijk in de pas met het inflatiepercentage sinds 1983. De toename wordt vooral veroorzaakt door aanwas van nieuwe wetten. ${ }^{15}$

Het telwerk levert ook een plaatje op. Dat vertoont overigens een zekere gelijkenis met een plaatje dat, over een langere periode (45 jaar), de productie van federale regelgeving in de Verenigde Staten weergeeft, zij het niet uitgedrukt in aantallen wetten maar in aantallen pagina's in de 'Code of Federal Regulations' (Dawson, 2007, p. 16-17). Dat er verschil in telwerk is, is niet zo heel erg omdat, zoals Dawson zegt, het 'reasonable is to believe that the number of pages of printed regulation is an indicator of the extent of regulation'. 
DAWSON (2007)

\section{JOHN W. DAWSON}

Figure 1

Federal Regulation in the U.S., 1949-1999

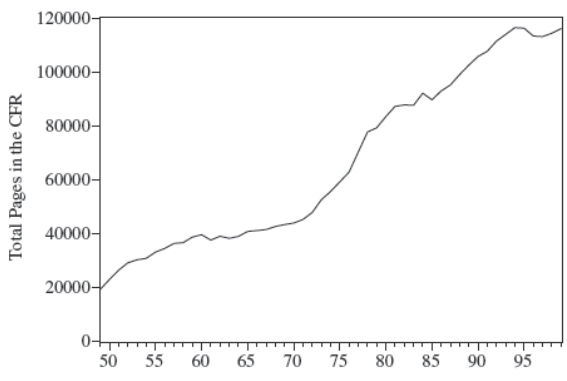

Source: Dawson and Seater (2006)

DE JONG \& HERWEIJER (2004)

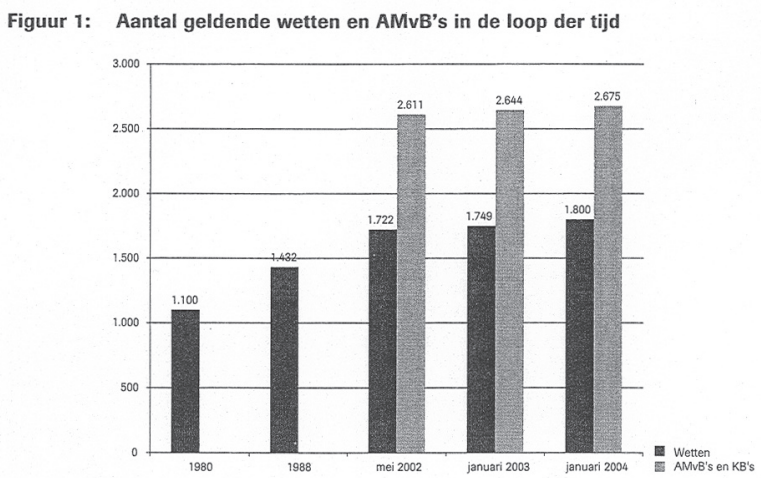

14 Overhoff en Molenaar, 1991, p. 5-6.

Informele regelgeving, zoals Veerman (2007b) het noemt ('handleidingen, circulaires, handreikingen' enzovoort), of pseudo-wetgeving, zoals anderen het noemen, zijn in deze cijfers niet inbegrepen. Toch gaat het daarbij niet om klein bier. Van 't Lam en Uylenburg (2006) inventariseerden voor het ministerie van Volkshuisvesting, Ruimtelijke Ordening en Milieubeheer (VROM) 183 van dergelijke regelingen, een kleine honderd meer dan het ministerie zelf dacht dat er waren.

Verondersteld kan worden dat bestuurders en politici wetgeving als 
een handzame, effectieve en doelmatige manier zien om gedrag te beïnvloeden. Immers, hoe anders zouden deze aantallen te verklaren zijn?

\section{Uitvoering van wet- en regelgeving: aantallen organisaties}

Wetten en daarmee verbonden (lagere) regelgeving moeten worden uitgevoerd en beleid moet worden ingevoerd, anders blijft het allemaal papier en dat kan toch niemand bedoeld hebben. Dat uitvoeringswerk wordt gedaan door ministeries en medeoverheden en door zelfstandige bestuursorganen en RWT's, oftewel rechtspersonen met een wettelijke taak. Overigens maken dit soort organisaties zelf ook weer informele regelgeving. ${ }^{16}$

\section{Wat zijn hier de aantallen?}

Er zijn in ons land een kleine drieduizend rechtspersonen met een wettelijke taak (RWT's), waarvan circa 13\% tevens zelfstandig bestuursorgaan (ZBO) is. Daarnaast zijn er nog zo'n driehonderd andere ZBO's, in totaal dus een ruime zeshonderd. Voorbeelden van RWT's die geen ZBO zijn, zijn de duizenden onderwijsinstellingen, de academische ziekenhuizen en de musea. Voorbeelden van ZBO's zijn Staatsbosbeheer, de NOS, het CBS, de Informatie Beheer Groep en de KNAW. Midden jaren negentig is door de Algemene Rekenkamer een aanvang genomen met het tellen van dit soort organen (Algemene Rekenkamer, 1995; 2004; Ministerie van Financiën, 2005; Jongeneel, 2005; Van Thiel, 2008; Van Thiel \& Van Buuren, 2001). Inmiddels bestaat er een ZBO-register en zijn er overzichten van aantallen RWT's. In 2004 ging een kleine 50 miljard euro van de rijksoverheid en een ruime 70 miljard uit premies en tarieven opgehaalde euro's naar deze organisaties om hun taken uit te kunnen voeren. Tabel 1 geeft wat preciezere cijfers (Van Thiel, 2008).

\section{Tabel 1.}

\section{Aantal verzelfstandigde organisaties in Nederland op rijksniveau}

\begin{tabular}{lrrr}
\hline & $\mathbf{1 9 9 3}$ & $\mathbf{2 0 0 0}$ & $\mathbf{2 0 0 4}$ \\
Zelfstandige bestuursorganen & 545 & 431 & 630 \\
Rechtspersonen met een wettelijke taak* & n.b. & 3.833 & 2.562 \\
Agentschappen & - & 17 & 34 \\
Stichtingen'7 & n.b. & n.b. & 335 \\
n.b. $=$ niet bekend & & & \\
${ }^{*}$ Inclusief schoolbesturen. & & & \\
${ }^{* *}$ Agentschappen bestaan pas sinds 1994. & & & \\
\hline
\end{tabular}




\section{Handhaving en Naleving: Aantallen Organisaties en de Aard en Omvang van Interventies}

Wetten en regels worden niet alleen bedacht, geformuleerd én ingevoerd, maar ze moeten ook worden nageleefd; en dát maakt dat ze ook moeten worden gehandhaafd. Niet iedereen doet immers wat de wet of de rechtsregel voorschrijft. $U$ kent dat probleem. Vandaar dat er organisaties zijn zoals de politie, het Openbaar Ministerie (OM) en de rechterlijke macht, die mensen en organisaties die niet doen wat (wettelijk) is voorgeschreven, aanpakken en waar nodig bestraffen. Toegespitst op het strafrecht is een doel enerzijds het herstel van de rechtsorde te realiseren door middel van het vergelden van het leed dat is aangedaan (het wraakargument), en door het herstellen van het leed bij slachtoffers (het genoegdoeningargument). Anderzijds gaat het om het verhogen van de veiligheid. Dit alles gebeurt door delinquenten op te sluiten, hen af te schrikken en hen trachten opnieuw in de samenleving te laten integreren via bijvoorbeeld reclasseringswerkzaamheden. Ook is een doel om mensen die nog (lang) niet op het foute pad zijn, afte schrikken door te laten zien wat er gebeurt als je strafrechtelijk wordt aangepakt (generale preventie). ${ }^{18}$

Sancties zijn er vele. Het gaat onder andere om door het OM opgelegde transacties en door de strafrechter (in eerste aanleg) opgelegde taakstraffen, (geheel of deels onvoorwaardelijke) vrijheidsstraffen en boetes. Uitvoerende instanties als DJI en Reclassering Nederland'9 voeren deze en een aantal andere maatregelen uit (zie verderop). Cijfers zijn te vinden in de tweejaarlijkse WODC-CBS-publicatie 'Criminaliteit en Rechtshandhaving' (2006); hier is het voldoende te constateren dat het jaarlijks om enkele honderdduizenden 'opleggingen, invoeringen en uitvoeringen' gaat (Van der Heide, Van Tulder \& Wiebrens, 2007).

Naast de eerdergenoemde actoren zijn er ook tientallen toezichthouders en inspecties die werk maken van naleving en handhaving van wet- en regelgeving. ${ }^{20}$ Soms heten ze Inspectie, soms Autoriteit en soms Commissariaat. Denkt u aan de Autoriteiten voor de Zorg, de Financiële Markten en de Mededinging, aan het Commissariaat van de Media, maar ook aan de Onderwijsinspectie, de Arbeidsinspectie en de Inspectie Verkeer en Waterstaat. Deze marktmeesters, regelmeesters en kwaliteitmeesters boden in 2006 aan zo'n tienduizend fte-ambtenaren werk. Toezicht door lokale organisaties is hier niet bij inbegrepen. Gezamenlijk houden deze organisaties toezicht op zaken die variëren van jeugd, gezondheid, gevangenissen en mobiele telefonie tot onder- 
wijs, milieu, bijstand en ontwikkelingssamenwerking. Zij turven, tellen en toetsen. Maar ze doen het ook via ingrepen, zoals boetes, processenverbaal, waarschuwingen, lasten onder dwangsom, bestuursdwang, intrekken van vergunningen, en via 'naming and shaming.'21 In totaal gaat het om tienduizenden maatregelen die toezichthouders en handhavers aan organisaties en mensen opleggen met het doel gedrag te bestraffen, ander gedrag te stimuleren of een voorbeeld te stellen aan derden die nog niet 'fout' bezig zijn. ${ }^{22}$ Tezamen met de eerdergenoemde actoren uit de (strafrechts)keten (de politie, het OM en de rechterlijke macht) zijn zij in 2006 goed voor zo'n 400.000 maatregelen van bestuursrechtelijke aard en een ruime 500.000 van strafrechtelijke aard (Willemsen, Leeuw \& Leeuw, in druk). ${ }^{23}$

\section{Het Instrumentenoverzicht Rijk en Overige 'Tools of Government' : Minderhedenbeleid, Onderwijsbeleid en Justitieel Sanctiebeleid als voorbeelden}

Toch is met dit alles nog slechts een deel van de wondere wereld van het interventionisme en het recht in kaart gebracht. Immers, alhoewel in veel gevallen gebaseerd op wet- en regelgeving, interveniëren overheden in de samenleving ook via tal van andere beleidsinstrumenten, zoals subsidies, garanties, voorlichtingscampagnes, veilingen, publiek-private partnerships, keurmerken, benchmarking, arbitrage en auditing.

Hoeveel van dergelijke instrumenten er in Nederland precies zijn, is niet bekend, want aan 'institutionele statistiek' doet het CBS (nog) niet. Wat er wel is, is het IOR, het Instrumentenoverzicht Rijk. Dat is een inventarisatie van alle geldstromen die 'het rijk verlaten' ten behoeve van de inzet van 'beleidsinstrumenten'.24 Eens per vier jaar zal de minister van Financiën dit overzicht presenteren, waarbij 2006 de eerste keer was. In dat jaar ging het om 515 beleidsmaatregelen, die voornamelijk als een subsidie of overdracht zijn te duiden. Samen waren zij in dat jaar goed voor circa 86 miljard aan rijksuitgaven. Het IOR is per ministerie en per subsidie geordend. De overige ruim 60 miljard aan uitgaven gingen op aan andere overheidsactiviteiten, zoals rentebetalingen, waaronder de rente op de staatsschuld, de beloning van ambtenaren en bestuurders, de aankoop van goederen en diensten, investeringen, het verstrekken van leningen, militaire uitgaven, en wat zo mooi heet 'interne verrichtingen' van de ministeries. Overigens waren er, toen de Algemene Rekenkamer voor het eerst in de Nederlandse staatsgeschiedenis het aantal rijkssubsidies telde - in 1988 - ruim zevenhonderd (De Kemp et al., 1989).25

Hoe informatief dit IOR ook is, de opsomming van vigerende 'tools of 
government' is nog steeds niet volledig. Immers, op een praktisch uitvoerend niveau, vaak in daarvoor speciaal opgerichte organisaties, zijn tal van specifieke maatregelen ingevoerd, waarmee gedrag van mensen geprobeerd wordt te beïnvloeden. Die worden weliswaar doorgaans gefinancierd uit publieke middelen en berusten ook vaak op wet- en regelgeving, maar inhoudelijk gaat het om heel andere typen interventies dan de wetten of rechtsregels zelve. Omdat er op dit uitvoerend niveau géén IOR is, beperk ik me tot drie velden om toch enig aanvullend cijferinzicht te geven. ${ }^{26}$

Het eerste veld is dat van het beleid gericht op het bevorderen van de integratie van allochtonen in de samenleving. In 2007 analyseerde het Sociaal en Cultureel Planbureau (SCP) de interventies gericht op het bevorderen van interetnische contacten en het tegengaan van etnische concentratie en telde zo'n zestien generieke maatregelen, terwijl het Wetenschappelijk Onderzoek- en Documentatiecentrum (WODC) de interventies telde die met integratie op de arbeidsmarkt te maken hebben en met maatregelen gericht op het tegengaan van criminaliteit van allochtonen. Dat waren er zo'n twaalf (Gijsberts \& Dagevos, 2007; KuluGlasgow et al, 2007). Voorbeelden die in de studies van beide instituten aan de orde kwamen, waren het Raamconvenant Grote Ondernemingen, het Landelijk Ondersteunings $\neg$ programma Mentoring, beleid inzake lokale multiculturele televisie, maar ook klushuizen(beleid) en maatregelen gericht op gentrification van wijken. Hoe vaak deze maatregelen worden ingezet, is onbekend. De SCP- en WODC-onderzoekers constateerden overigens ook dat de kennis over de effectiviteit van al dit moois gering is.

Het tweede veld is dat van het onderwijs, ook vroeger al bekend om zijn aanzienlijke hoeveelheden regelgeving. Een voorbeeld maakt dat duidelijk. Alleen al in en met de Wet educatie en beroepsonderwijs (de WEB) wordt op tientallen manieren geprobeerd het middelbaar beroepsonderwijs en zijn 'Umfelt' te beïnvloeden. Een analyse door Hulshof en mijzelf (2007), op verzoek van de Onderwijsraad uitgevoerd, laat zien dat er in deze WEB cum annexis 197 zinsneden zijn aan te treffen die pogingen beschrijven actoren in en rond het beroepsonderwijs te beïnvloeden via sancties, 149 keer via vooral financiële of reputationele prikkels, zoals beloningen, en 192 keer via voorlichting, informatieverspreiding en het certificeren van opleidingen.

De Onderwijsraad (2007) ging verder en liet de aantallen interven- 
ties van overheidswege bij acht onderwijsthema's tellen. Het waren er zo'n 220, die probeerden iets te doen aan de lerarenproblematiek, de onderwijstijd, het innovatief vermogen van en rond scholen, onderwijsachterstanden en het vroegtijdig schoolverlaten. Het advies dat de Onderwijsraad aan zijn analyse verbond, komt er in de kern op neer dat beter nagedacht moet worden vooraleer dit soort interventies wordt ingevoerd. Immers, maatregelen werken elkaar soms tegen, zijn ongekend in hun effectiviteit, en waaieren ook nog wel eens uit.

Het derde veld is het beleid van justitiële inrichtingen en de reclassering waar het gaat om de tenuitvoerlegging van sancties. Van der Heide, Van Tulder en Wiebrens (2007, p. 43) plaatsen dit onderdeel in een bredere context. 'Het Nederlands recht kent een grote diversiteit aan strafrechtelijke sancties waarmee verdachten en schuldigverklaarden worden geconfronteerd: van transacties tot tbs-maatregelen. Het gevolg van deze diversiteit is dat er vele, sterk van elkaar verschillende instanties bestaan, die sancties ten uitvoer leggen.' Zo zijn er vrijheidsbenemende sancties (gevangenisstraffen, tbs-opleggingen en voor jeugdigen: de PIJ-maatregel ${ }^{27}$ ), vrijheidsbeperkende sancties (zoals taakstraffen meerderjarigen, taakstraffen minderjarigen en Halt-afdoeningen) en flink wat overige sancties. Denk daarbij aan ontnemingen van wederrechtelijk verkregen voordeel (de 'pluk-ze-activiteiten'), schadevergoedingen en de verbeurdverklaring en onttrekking van goederen aan het maatschappelijk verkeer. Bij dat laatste betreft het een divers scala aan goederen die in beslag genomen worden, waaronder auto's, maar ook hennepkwekerijen.

Jaarlijks gaat het, zoals eerder gezegd, om enkele honderdduizenden sancties die opgelegd worden. Er bestaan bovendien tal van specifieke maatregelen, zoals agressiebeheersingstrainingen, arbeidstrainingen, leefstijltrainingen, woontrainingen, delictpreventietrainingen, cognitieve-vaardighedentrainingen en zelfconfrontatieprogramma's. ${ }^{28}$ Maar het gaat ook om sociale-vaardigheidprogramma's, functionele familietherapie, trainingen morele ontwikkeling, 'Brains for use' gericht op verslaafden, en om 'vertrektrainingen', om de weg naar de samenleving buiten de poort van de instelling te optimaliseren (Poort \& Eppink, in druk). Het gaat niet om klein bier. Uit cijfers van Reclassering Nederland blijkt dat er bijvoorbeeld jaarlijks zo'n kleine 30.000 toezichtactiviteiten worden ondernomen, gericht op zo'n 12.000 mensen. En in de tbs-wereld ${ }^{29}$ wordt met supervisieprogramma's, dagbehandelingsprogramma's en farmacologische interventies getracht invloed op het gedrag van tbs'ers 
te hebben. ${ }^{30}$

Zoals het WODC en andere onderzoeksinstituten regelmatig moeten laten zien, leveren de interventies lang niet altijd de verwachte en gehoopte effecten op. Bovendien zijn het er, ook volgens het ministerie van Justitie, te veel, reden om een Erkenningscommissie van experts in te stellen om het kaf van het koren aan (gedrags)interventies te scheiden. ${ }^{31}$

\section{Private wet- en regelgeving: lookalike van beleidsinterventies}

Ik kom toe aan de laatste en voor sommigen van u wellicht minder bekende loot aan de interventieboom: de productie van regelgeving door wat Giesen (2007, p. 75) 'private wetgevers' noemt. Giesen doelt op rechters, die - naast de publieke wetgever - 'private verhoudingen door algemene regels reguleren en niet langer enkel en alleen door onderlinge afspraken of overeenkomsten'. Cruciaal is dat het om méer dan alleen zelfbinding of zelfregulering gaat. Het gaat om 'binding van derden' (Giesen, 2007, p. 115). Uiteraard is dit fenomeen ouder dan vandaag en gaat het in zekere zin terug tot het Lindenbaum-Cohen-arrest van de Hoge Raad uit het begin van de twintigste eeuw, ${ }^{32}$ maar recente (juridische) beschouwingen maken duidelijk dat er de afgelopen tijd sprake is van een intensivering van de productie van deze rechtsregels. Voorbeelden van interventies van private wetgevers zijn onder andere behandelingsprotocollen in de gezondheidszorg en rechtersrecht (vgl. Rijpkema, 2001).33 Van Boom (2003, p. 3-4) geeft andere voorbeelden, die met name rondom het veiligheidsvraagstuk spelen. 34 Hij laat zien dat rechters optreden als 'veiligheidsregulerende instanties', vooral daar waar sprake is van door hen waargenomen 'structurele veiligheidsfouten' in een organisatie, op een werk, ten aanzien van een procedure, een techniek of een voorziening. 'Een rechterlijke uitspraak over structurele fouten heeft gevolgen die verder reiken dan het concreet beslechte geval (...) Deze uitspraken strekken ertoe de veiligheid van de leefomgeving te reguleren.' Van Booms voorbeelden (2004, p. 8) variëren van eisen waaraan schuifpuien in conferentieoorden, speeltoestellen en gymnastiekinrichtingen moeten voldoen, tot de toegestane hoogte van bomen bij kruispunten met verkeerslichten, de aard van de balspelen op scholen en de eisen waar kelderluiken in cafés aan dienen te voldoen. Hij merkt bovendien op dat rechters zich weliswaar kunnen 'aansluiten bij het door de wetgever in voorschriften neergelegde niveau van veiligheidsregulering', maar vaak is het ambitieniveau hoger. Privaatrecht 
bestaat voor een deel uit gedragsregels die gehandhaafd worden met klassieke remedies, zoals schadevergoeding, nietigheid, ontbinding en vernietiging. ${ }^{35}$ De veronderstelling is dat de doelen die de regelgever nastreeft, met naleving van de betreffende regel bereikt kunnen worden (Van Boom, 2007, p. 983). Niet voor niets spreken Van Boom maar ook Genn, Partington en Wheeler (2006) wel over 'civilologie'. ${ }^{66}$ Rijpkema (2001, p. 70) analyseerde eerder ook rechtersrecht, waarbij hij eveneens oog had voor het verschijnsel dat dit recht 'consequenties heeft voor niet bij het geding betrokken derden en [voor het verschijnsel; FLL] dat een nieuw geformuleerde rechtsregel ook voor hen onvoorzienbare gevolgen kan hebben'.

Gaan Giesen (2007) en andere juristen vooral in op juridische aspecten van deze private, ook wel alternatieve of reflexieve regulering genoemd (zoals de ermee samenhangende mogelijke rechtsonzekerheid, p. 117, de gevolgen voor de trias politica (p. 124) en de concurrentie die kan ontstaan tussen 'de oorspronkelijke twee rechtsvormers, wet-

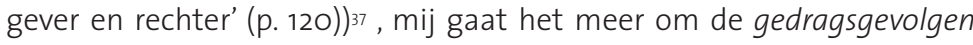
van het op deze manier handelen van rechters. Immers, hoe het ook zij, deze rechtsregels zijn in wezen interventies, die beogen invloed uit te oefenen op het handelen van natuurlijke personen en rechtspersonen, en niet alleen van de direct betrokkenen in een proces..$^{8}$ Dat juristen oog voor deze thematiek hebben, laat ook het boekje van Farnsworth (2007) The Legal Analyst zien, waarin hij zijn collega's oproept serieus werk te maken van ex-anteanalyses van de gevolgen van uitspraken en vonnissen voor anderen dan de deelnemers aan een gerechtelijke procedure zelf. Hij draagt interessante gedragswetenschappelijke en (rechts)economische benaderingswijzen aan hoe dit te doen. ${ }^{39}$

I $\mathrm{k}$ vind het opvallend dat in beschouwingen over het terugdringen van wet- en regelgeving de laatste jaren aan deze loot aan de interventieboom grotendeels voorbij is gegaan. Zo is er nooit geteld om welke aantallen interventies het gaat, die door private wetgevers geproduceerd worden, om Giesens woordkeuze nog eens over te nemen..$^{\circ}$ Dat is jammer, temeer omdat deze ontwikkeling, zoals Witteveen en Gribnau (2005, p. 3) laten zien, verband houdt met het verschijnsel dat 'statelijke rechtsvorming meer en meer plaats moet maken voor maatschappelijke rechtsvorming. Steeds meer actoren dragen bij aan de (niet meer hiërarchisch gerangschikte) rechtsontwikkeling, zodat de gewone wetgever niet langer exclusief is, als dat ooit al het geval is geweest.' Hirsch Ballin's 
(1999) concept van de multipolaire rechtsontwikkeling sluit hierbij aan. In zijn studie naar 'netwerken van rechtsontwikkeling' zet hij de geschiedenis van dit denken uiteen, waarbij hij afscheid neemt van Kelsens (1992) Stufentheorie der Rechtsordnung. Ging Kelsen, die overigens bevriend was met de Oostenrijkse econoom Ludwig von Mises ${ }^{41}$ nog uit van niveauverschillen bij de rechtsordening, waarbij 'die Verfassung' het hoogste niveau betrof en 'Gesetzgebung' een goede tweede werd, Hirsch Ballin (1999, p. 26) betoogde al een kleine tien jaar geleden dat daar in Nederland géén sprake meer van is.

Hoe interessant juridisch gezien deze ontwikkeling ook is, voor mij is interessanter dat wat op deze manier tot stand wordt gebracht, regels en afspraken zijn die beogen het handelen van burgers en organisaties te beïnvloeden in deze of gene richting dan wel 'versterker' te zijn van gedrag dat reeds gepleegd wordt en gewenst wordt bevonden.

\section{Interventionisme anno nu: geen muizenbeetje}

Het totale aantal interventies dat in Nederland wordt ingezet vanuit de publieke sector, dan wel met behulp van publieke financiering tot stand komt, is met dit alles dus aanzienlijk groter dan wat het Instrumentenoverzicht Rijk toont, of wat het eerdere tel- en rekenwerk betreffende wetten laat zien. En dan zijn interventies van medeoverheden, waaronder gemeenten en provincies, nog niet meegenomen en geldt dat ook voor Europees en internationaal beleid, respectievelijk wet-en regelgeving. ${ }^{42}$

De conclusie die zich opdringt, is dat onze samenleving anno 2008 gekenmerkt wordt door een aanzienlijke hoeveelheid interventionisme. Hoeveel interventionisme er precies is en hoeveel meer of hoeveel minder dan dertig jaar geleden, is niet goed te zeggen, maar het is geen muizenbeetje. Over de impact van het streven van het huidige kabinet om tot minder regels en minder toezicht te komen, is wetenschappelijk gezien nog weinig of niets te zeggen, omdat de voornemens nog niet full swing geïmplementeerd zijn. Het decennialang hameren, door de Algemene Rekenkamer, op het belang van evaluatieonderzoek en prestatiebegrotingen heeft weliswaar het een en ander opgeleverd waar het de direct telbare prestaties van interventies betreft, en ook wat de omvang van het evaluatieonderzoek betreft, maar veel minder als het om de maatschappelijke effecten van interventies gaat.43

Alles overziende zou wijlen Ludwig von Mises ${ }^{44}$ ongetwijfeld van 
mening zijn geweest dat zijn 'Kritik des Interventionismus' uit 1929 nog steeds de moeite waard was om gelezen te worden.

\section{Gedragsmechanismen als motoren achter interventies en regels}

Wie hoopt dat ik me, op deze vrijdagmiddag, daarom nu ga richten op de vraag of het niet beter ware tot veel minder interventionisme te komen, heeft pech. Dat is niet primair 'my piece of cake'. Ik kan me overigens wel goed voorstellen dat sommigen uwer gruwen van al die beleidsmaatregelen en regels, en hopen op een spoedig moratorium. ${ }^{45} \mathrm{lk}$ zelf wilde het wat betreft de politiek daar thans even bij laten. Immers, de schets tot nu toe is vooral bedoeld te functioneren als 'institutioneel behang', om $u$ gereed te maken voor een analyse van de gedragsmechanismen, die aan interventies van overheidswege en aan rechtsregels ten grondslag liggen.

Gedragsmechanismen zijn, kort gezegd, de motoren achter interventies en rechtsregels..$^{6}$ Of zoals Elster (1989, p. 3; 2007, p. 36) het uitdrukt: het zijn de 'cogs and wheels that have brought the relationship [tussen interventie en uitkomsten; FLL] into existence'. Wetenschapsfilosoof Bunge zegt het net wat anders. 'Mechanisms are sequences of causally linked events that occur repeatedly in reality if certain conditions are given. (...) Mechanisms state how, by what intermediate steps, a certain outcome follows from a set of initial conditions' (Bunge, 1997, p. 439).

Als ik wat voorbeelden geef van dergelijke mechanismen, gaat het meer leven.

Denk aan het menselijk streven om, zoals psychologen dat noemen, cognitieve dissonantie te reduceren: mensen zijn doorgaans liever niet met zichzelf in tegenspraak en doen er van alles aan om onevenwichtigheden tussen kennis, houdingen en gedrag uit de weg te gaan of te voorkomen.

Een ander mechanisme is dat van 'the shadow of the future', dat in speltheoretisch onderzoek is gedetecteerd: als mensen contractuele relaties met elkaar aangaan en ze beschikken over niet veel alternatieven om hun doelen te bereiken, dan houden de contractpartners er rekening mee dat ze langer met elkaar door één deur moeten. Die afweging maakt dat ze vaak netjes naar elkaar zijn en dat ook blijven, en elkaar niet voor van alles en nog wat vernachelen. De combinatie van de te verwachten baten van de samenwerking in de toekomst en het nu niet hebben van 
goede 'exit'-opties, is een belangrijk onderdeel van dit mechanisme.

Een derde voorbeeld is dat mensen leren door af te kijken hoe anderen iets doen, en het afgekeken gedrag vervolgens imiteren. Met een chic woord heet dat 'vicarious learning'(Bandura, 1983). Dit mechanisme doet zich niet alleen voor tussen mensen, maar ook tussen organisaties; organisaties kijken en luisteren naar elkaar, wegen elkaar en doen dan vaak hetzelfde, zij het onder verschillende namen, want het is natuurlijk niet zo slim om te zeggen dat je de boel imiteert (Scott, 2003; Frumkin \& Galaskiewicz, 2004).

Relatieve deprivatie is weer een ander gedragsmechanisme, voortgekomen uit sociologisch onderzoek. Voor mijn geluk en zaligheid doet het er niet alleen toe hoe het mij vergaat, maar vooral hoe het mijn 'belangrijke anderen', met wie ik te maken heb en met wie ik me vergelijk, vergaat. Als het met mij een beetje aardig gaat, maar met mijn significant others stukken beter, dan ervaar ik relatieve deprivatie. En dat beïnvloedt mijn gedrag méér dan het simpele feit dat het mij, naar mijn eigen maatstaven, redelijk goed gaat.

Cascade(vorming) is een mechanisme waar onder andere Kuran en Sunstein (1999) studie van maken.48 Het verhaal dat wijlen Beatlesmanager Brian Epstein van de eerste officiële (EMI-)single van deze groep zelf tientallen exemplaren kocht om op die manier het beeld te creëren dat de muziek van deze Liverpudlians de moeite van het kopen waard was, illustreert dit mechanisme. ${ }^{49}$

Crowding out is een mechanisme waar economen en psychologen op geattendeerd hebben. In zijn kern komt het erop neer dat het formaliseren in regels van gedrag en afspraken tussen mensen ertoe leidt dat zij het betreffende gedrag juist niet meer uit zichzelf gaan vertonen (Van Bijnen, 2005, p. 110 e.v.; Croes, 2007). De formele normen, neergelegd in wetten of regelingen of in andere oekazes, ontnemen de informele normen en verwachtingen hun - oorspronkelijk - krachtige werking.

In psychologisch onderzoek naar de manier waarop burgers, maar ook rechters, politiefunctionarissen en artsen beslissingen nemen, zijn ook belangrijke gedragsmechanismen gedetecteerd. Denkt $u$ aan de fundamentele attributiefout (als een beslissing goed uitpakt, ben ik de oorzaak, gaat het fout, de ander, het weer of de omstandigheden) en het 
framing-mechanisme (hoe we iets duiden, bepaalt mede wat ons gedrag is). 'Tend and befriend'en 'fight or flight'zijn weer andere voorbeelden.

Ook (rechts)economen maken studie van mechanismen achter gedrag, zoals de ontvangers van de Nobelprijs 2007 lieten zien. Die ging naar een drietal heren (Hurwicz, Myerson en Maskin) voor hun werk op het gebied van mechanism design theory. Centraal daarin staat het bedenken en testen van theorieën over mechanismen en instituties met het doel markten hun werk beter te laten doen. Dichter bij huis schreef mijn Maastrichtse collega Riedl over een mechanisme dat bij belastingwetten een belangrijke rol speelt. Het gaat schuil achter het volgende rijmpje: 'don't tax him, don't tax me, but tax the man behind the tree' (Riedl, 2006, p. 23).50

In de neurowetenschappen, ten slotte, wordt uiteraard ook veel kennis geproduceerd over mechanismen die het gedrag van mensen bepalen of op zijn minst beïnvloeden. Het gaat om kennis die van belang is bij het analyseren van beleidsinterventies en rechterlijke sancties, maar ook bij het ontwerpen ervan. De Kogel (2008) laat in een recente overzichtsstudie onder andere zien dat een gedragsinterventie in een gevangenis of tijdens een reclasseringstraject een minder goed resultaat heeft bij delinquenten die door beperkingen in het functioneren van gebieden in de prefrontale hersenen niet goed in staat zijn een strafdreiging op waarde te schatten, of hun gedrag slecht kunnen bijsturen. Ook wijst ze erop dat oudertrainingen vermoedelijk weinig effect sorteren als een kind door afwijkingen in het functioneren van de amygdala ongevoelig is voor straf, of als het door slecht functionerende spiegelneuronen niet goed in staat is tot vormen van gevoelsmatige empathie te komen.

Bij het verklaren hoe het komt dat interventies zoals wetten, regels, convenanten, toezichtarrangementen, opvoedingsprogramma's, agressietrainingen, voorlichtingscampagnes, subsidies, (bestuurlijke) boetes en al wat ik $u$ eerder noemde, soms wel, maar vaak ook niet werken ${ }^{51}$, is kennis over (dit soort) mechanismen wezenlijk. De interventies beogen immers gedragsmechanismen te activeren in een richting, die beleidsmatig of op grond van magistratelijke uitspraken wenselijk is. De prikkeling vindt uiteraard niet in het luchtledige plaats, maar loopt aan tegen de gevolgen van eerder gedrag. Dat eerdere gedrag komt voort uit hersenen, hormonen en instincten, uit rationele afwegingen, uit het volgen van culturele patronen en uit padafhankelijkheden. Activatie 
van gedragsmechanismen door interventies moet dus concurreren met deels ingesleten en gestolde gedragspatronen.

Daarbij maakt het overigens uit of interventies zoals wetten of regels door open normen gekarakteriseerd worden, of juist niet, of - om een ander voorbeeld te noemen - wet- en regelgeving slechts kaders aangeeft waar rekening mee gehouden moet worden, of juist pietje precies doelen specificeert. Een interessante bevinding is dat de sturende rol van gedragsmechanismen doorgaans aanzienlijk belangrijker wordt geacht dan dit soort meer formele kenmerken (Veerman, 2007a).

Interventies bereiken lang niet altijd uit zichzelf de mensen of organisaties waar het om gaat, maar moeten, zoals dat in bestuurskundigenjargon heet, geïmplementeerd worden. Ook dan spelen gedragsmechanismen een belangrijke rol. Een deel van de implementatieproblemen waar in beleidskringen zo vaak over wordt gesproken, komt voort uit het feit dat men bij de implementatie uitgaat van twijfelachtige en soms foute veronderstellingen over gedrag van mensen. ${ }^{52}$

Het beeld dat ik schets, bestaat eruit dat vergunningen, convenanten, voorlichting, heffingen, sancties, verdicten en de talloze andere interventies gedragsmechanismen beogen te triggeren in een richting die, althans als ze het goed doen, beleidsmatig of (juridisch-)normatief als wenselijk wordt gezien. Die kennis helpt ook bij het begrijpen van het onderscheid tussen 'law in the books'en 'law in action', waar, zoals velen van u weten, een aanzienlijk verschil tussen bestaat. Dat alles maakt dat het cruciaal is te weten op welke gedragsmechanismen interventies en rechtsregels een beroep doen.

As simple as that. Helaas, dát is toch niet het hele verhaal. Drie aspecten compliceren het beeld.

\section{Drie Complicaties: Over beleidshomeopathie, de rol van contexten en 'Tant de bruit pour rien'}

De eerste complicatie is dat beleidsmakers soms, maar soms ook vaak, interventies bedenken en invoeren die mechanismen beogen te activeren, die niet werken of die de strijd met wat ik eerder ingesleten gedragspatronen noemde, verliezen. Denk aan het geven van informatie over de ernst van zwerfvuil, waarvan verondersteld wordt dat die informatie zal aanslaan maar dat helaas vaak niet doet, omdat de afstand tussen het voorlichtingsfoldertje en het gemak van het weggooien van 
lege colaflesjes te groot is. Het idee foute jongens op te bergen en te heropvoeden in enigszins op boot camps gelijkende inrichtingen, waardoor ze minder delinquent worden, ziet veel over het hoofd, waaronder het mechanisme dat het voor hen aantrekkelijker is stoer en crimineel te zijn dan zich aan de moraal van de inrichting en de samenleving te houden. Als ze dan ook nog last hebben van meer dan reguliere hoeveelheden cortisol op bepaalde momenten van de dag, dan helpen die heropvoedingskampen in het geheel niet. Of, om het over andere zware jongens te hebben: het idee dat het openbaar maken van topsalarissen de hoogte van deze salarissen in de toekomst mitigeert, pakte anders uit, onder andere omdat geen enkele raad van commissarissen ertoe overgaat 'zijn' leidinggevenden bewust en bedoeld in het onderste kwartiel van de verdeling te plaatsen. Maar ook omdat directeuren, onder verwijzing naar de openbare salarisgegevens van ándere bedrijfsleiders, hun raad van commissarissen weer onder druk kunnen zetten richting meer en meer. Een dure en niet-effectieve manier om te helpen voorkomen wat ik eerder relatieve deprivatie noemde.

Dames en heren, zo kan ik nog wel even doorgaan. Evaluatieonderzoek toont regelmatig aan dat interventies geen doel treffen en daarmee soms weggegooid geld zijn. Dergelijk onderzoek toont óók aan dat dat voor een belangrijk deel komt, omdat de veronderstelde of gehoopte interventiemechanismen anders uitpakken dan gehoopt was of helemaal niets 'doen'. De theorie die aan het beleid of de interventie ten grondslag ligt, is met andere woorden incorrect. Tongue in cheek zou je kunnen spreken over heel wat beleidshomeopathie in de wereld van het openbaar bestuur en het recht.

Dat steekt schril af tegen wat in een Editorial in The Lancet van 27 augustus 2005 te lezen was onder de titel 'The End of Homeopathy'. Een hoofdredactioneel commentaar onder een gelijkluidende titel in het Nederlands Juristenblad of in B en M, Tijdschrift voor Beleid, Politiek en Maatschappij zie ik nog niet zo snel verschijnen.

Om het nog wat erger te maken, wil ik graag een licht ontluisterende Haagse ervaring van recente datum met $u$ delen, die alleen maar meer homeopathie in bestuur en beleid zal veroorzaken. Sinds enige tijd zijn er zogenaamde instrumentenplanners op het internet beschikbaar. Het zijn digitale vraag- en antwoordspelen die als volgt werken. $U$ tikt uw maatschappelijk of beleidsprobleem in, $u$ geeft aan om welke groepen 
mensen het gaat, en $u$ beantwoordt nog een achttal andere vragen. Dan drukt $u$ op de OK-toets. Nog voordat $u$ van het handen wassen in onschuld terug bent, hebt $u$ een rangordening van circa 25 beleidsinterventies op uw beeldscherm staan. Richt een Taakgroep in, Doe een Heffing, Geef Voorlichting, Verander de Wet enzovoort. Dialoog over wat de instrumenten effectief kán of zal maken, is afwezig. En evenmin prikkelt de 'voorziening' op zoek te gaan naar wetenschappelijke kennis ter toetsing van het digitale advies. Het is vooral een tick and flick-dingetje, dat eerder tot meer beleidshomeopathie aanleiding zal geven dan tot minder. Wilt $u$ het zelf eens bekijken, surf dan naar de instrumentenwijzer.nl, de novem.energiebesparingsinstrumentenwijzer.nl of een van de andere, want ze zijn toch allemaal grotendeels hetzelfde. ${ }^{53}$

Ik sprak zonet over drie omstandigheden die het beeld van de verhouding tussen interventies en rechtsregels enerzijds en gedragsmechanismen anderzijds compliceren. Maar tot nu toe kreeg u er slechts een.

De tweede complicatie is de volgende. Alhoewel kennis over de werking van mechanismen cruciaal is om te begrijpen waarom overheidsinterventies werken of niet, is ook de context medebepalend voor de effectiviteit ervan. Een pakkansverhogende maatregel gericht op de bestrijding van criminaliteit werkt in een dictatuur anders dan in een samenleving waarin emotietelevisie, een alles-moet-kunnencultuur en de verzorgingsstaat hand in hand gaan. We zijn er dus niet met alleen kennis over mechanismen, maar we moeten ook over kennis beschikken die de relatie tussen contexten en mechanismen aangaat. Met een variant op de epigenetica54 moeten we meer werk maken van wat de bepalende kenmerken van contexten zijn die gedragsmechanismen aan- of uitzetten. Wat is het binnen een sociale omgeving dat maakt dat mensen soms geheel tegendraadse en onverwachte afwegingen maken, of wat maakt dat verrijkte leeromgevingen sommige jongeren kunnen stimuleren beter op school te presteren, maar anderen ijs- en ijskoud laat?

De derde complicatie is de volgende. Voor wie goed naar interventies en hun 'architectuur' kijkt, ziet dat veel interventies een beroep doen op goeddeels dezelfde gedragsmechanismen. Anders gezegd: tal van als bijzonder, specifiek, situationeel bepaald, nieuw en nieuwer dan nieuw verkochte beleidsinterventies van kabinetten, ministers, provinciale bestuurders, schouten en schepenen en rechters doen vaak op dezelfde 
- en beperkte - set aan mechanismen een beroep. Op zichzelf is dat niet zo gek, want het komt wel vaker voor dat een beperkte set van het een of ander meerdere doelen tegelijkertijd kan bereiken. Multitasking heet dat. Wie daaraan in de wereld van beleid en recht doet, moet ten eerste goed weten dat de gedragsmechanismen ook werken zoals beoogd, want als dat niet zo is, is het weggegooid geld. Daar komt als probleem bij dat beleidsinterventies, rechtsregels en vonnissen veelal niet informatief zijn over de mechanismen die geactiveerd moeten worden. Het kost dus tijd en energie om erachter te komen dat nieuw beleid of nieuwe wetgeving, vaak chic verpakt in nota's, eigenlijk niet meer is dan meer van hetzelfde. 'Tant de bruit pour rien.'

Laat mij dit illustreren aan de hand van enkele recente WODConderzoeken. Ik informeerde $u$ zonet over hoeveel wetten op jaarbasis worden gemaakt door Den Haag. Of die effectief zijn, weet je uiteraard pas later en doorgaans pas na onderzoek. Het WODC synthetiseerde de resultaten uit 75 sinds 1995 door de ministeries verrichte wetsevaluaties (Klein Haarhuis \& Niemeijer, 2008). Het gaat om verschillende actoren, normen, geadresseerden en terreinen, de laatste variërend van wetgeving gericht op het bedrijfsleven, het onderwijs en landbouw tot de gezondheidszorg, justitie en arbeidsverhoudingen. Wat blijkt is dat hoe gedifferentieerd de verzameling van wetten ook is, het steeds maar een beperkt aantal gedragsmechanismenss is dat ervoor moet zorgen dat de wet doet wat hij moet doen. Klein Haarhuis en Niemeijer noemen ten eerste het (sociale) mechanisme van de kosten-batenafweging, vormgegeven via vooral financiële prikkels, zoals subsidies en afdwingbare ge- en verboden. Een tweede mechanisme is dat van de overreding en communicatie. Zonder dat kunnen normadressaten niet weten wat ze moeten doen of laten, en kunnen zij de wet dus ook niet in de praktijk brengen. Dit aspect blijft echter opvallend impliciet in wetten, zo schrijven de WODC-onderzoekers. Het derde gedragsmechanisme is het bescherming verschaffen. Personen die zwakker (dreigen te) staan en extra rechtsbescherming behoeven (bijvoorbeeld minderheden of adoptiekinderen), worden bij wet beschermd. Het vierde gedragsmechanisme is dat van de rechtshandhaving.

De door Klein Haarhuis en Niemeijer (2008) onderzochte tientallen wetten en wetsevaluaties maken in overheersende mate dus gebruik van slechts enkele gedragsmechanismen, zoals prikkels, dwang en voorlichting. Wat specifiek, bijzonder, complex en situationeel bepaald lijkt (wetgeving op al die verschillende terreinen), is bij nader onderzoek 
eigenlijk vooral meer van hetzelfde (Veerman, 2007a). Overigens constateren de onderzoekers ook dat de mate waarin de wetten doel treffen, óf onbekend is óf beperkt. . $^{6}$

Ik geef $u$ een tweede voorbeeld. Begonnen met een inventarisatie van tegen de 500 - vooral buitenlandse - evaluaties van programma's gericht op het voorkomen en tegengaan van geweld in de publieke ruimte, hielden Van der Knaap en haar collega's (2006; 2008; vgl. Leeuw, Van der Knaap \& Bogaerts, 2007) 36 programma's over, die op methodologisch correcte wijze waren geëvalueerds7 (in 48 publicaties). Van die programma's waren er negen effectief. Dat is niet veel. Wat effectief bleek te zijn, waren bijvoorbeeld doelgericht politieoptreden (in vaktaal: hot spots policing), beter licht in publieke ruimtes en programma's die mensen vaardigheden aanleren om geweld te voorkomen. Bij dieper kijken bleek het echter maar om drie basale mechanismen te gaan. Het eerste mechanisme was leren, leren en nog eens leren. Het is zoiets als wat door een negentiende-eeuwse Nederlandse schrijver wel werd aanbevolen aan studenten: 'Heren, heren, heren, het enige wat ik $U$ kan adviseren, is studeren, studeren, studeren.' Het tweede mechanisme bleek het door de sociale omgeving belonen, respectievelijk bestraffen van gedrag te zijn door middel van 'bonding' en 'binding' en door het optreden van de politie. En het derde mechanisme was simpelweg 'risicoreductie'.

De wat droeve constatering is dat er een kleine veertig programma's op een serieuze manier geëvalueerd zijn, dat om dat te weten zo'n vijfhonderd studies moeten worden opgespoord en deels worden doorgeakkerd, dat van die programma's er maar negen werken, en dat die negen op drie basale gedragsmechanismen 'aangrijpen' . De discrepantie tussen interventies en gedragsaspirines, als ik het zo mag noemen, is daarmee aanzienlijk.

Onderzoekers zoals Elster (1989; 2007), Coleman (1990), Hedström en Swedberg (1998), Mayntz (2004) en Farnsworth (2007) laten zien dat er maar een relatief beperkt aantal 'behavioral mechanisms' is, waarvan we weten dat ze werken. In ieder geval aanzienlijk minder dan de sheer magnitude aan overheidsinterventies, waar ik u zonet over informeerde. Buchanan (2007) heeft in zijn boekje 'The Social Atom' onlangs nog weer eens laten zien dat veel zogenaamd uiterst complexe sociale processen teruggrijpen op vaak enkele, maar wel krachtige patronen en oorzaken 
van (geaggregeerd) individueel gedrag (vergelijk ook Ultee, Flap en Arts, 2003). Sociologen die werken vanuit het methodologisch individualisme, stellen uiteraard wel de vraag hoe gegevenheden op macroniveau inwerken op individuen én hoe, omgekeerd, uit de aggregatie van handelingen van die individuen nieuwe maatschappelijke fenomenen ontstaan ('spontane ordeningen', wet- en regelgeving enz.)..$^{8}$ In een boekje dat het onderwerp van deze oratie uitdiept en dat volgend jaar verschijnt, geef ik een overzicht van enkele tientallen mechanismen, gebaseerd op literatuur uit de gedrags- en maatschappijwetenschappen, waaronder de economie en de biologie, en uit verschillende interdisciplinaire velden, zoals de rechtspsychologie en 'behavioral economics'.

\section{Hoe dit te verklaren?}

\section{Over 'Inside Bureaucracy', imitatiegedrag, verkokerde geleerdheid en (vrij) eenzijdig evaluatieonderzoek}

Het is niet ondenkbaar dat bij $u$ inmiddels de vraag is gerezen hoe het te verklaren is dat er flink wat homeopathie en ineffectiviteit bestaat in de wereld van bestuur, beleid en het recht. 59

Ter beantwoording van deze vraag grijp ik onder andere terug op onderzoeksbevindingen van 'public choice-economen' en organisatiesociologen.

Het komt ten eerste omdat politici en voor hen werkende hoofdambtenaren streven naar behoud, dan wel naar méér 'turf', zoals Amerikanen het noemen, oftewel naar meer invloed, aanzien, functiereikwijdte en macht (Downs, 1957; 1967; Wilson, 1989; Mueller, 2003). Dat bereik je allemaal niet door te zeggen:

- dat nieuw beleid eigenlijk oud beleid is;

- dat het allemaal simpeler kan;

- dat je het ook niet weet; en

- dat niets doen wellicht beter is dan homeopathische interventies voorschrijven.

Er is ook een tweede verklaring: imitatiegedrag. Wat in landen waarmee Nederland zich wel vergelijkt, aan tools of government wordt waargenomen, wordt vervolgens ook hier ingevoerd, soms na aanpassing aan 'nationale' omstandigheden. Paul Light schrijft over golfbewegingen in de publieke sector in de Verenigde Staten en laat zien om welke golven het gaat en hoe ze te duiden zijn (Light, 1997; 2006). Imitatiegedrag ligt 
bijvoorbeeld deels ten grondslag aan de tendens van de afgelopen vijftien jaar om veel te verwachten van toezicht, inspectie en 'regulation'. Eerder gold dat voor privatisering en sinds kort geldt het voor het geloof in government by governance. Dat is te vinden in het hoger onderwijs, de thuiszorg en de volkshuisvesting, om een paar dwarsstraten te noemen. Meer van hetzelfde, een zeker papegaaiengedrag, maar met vaak géén oog voor de centrale vraag of deze spullenboel aan interventies en regels wel gedragswetenschappelijk kan en zal werken.

Toch, dames en heren, zijn we er hiermee niet. Immers, zo geformuleerd is het probleem in zijn geheel te wijten aan bestuurders, politiek, juristerij en ambtenarij. Zo is het natuurlijk niet. Het wetenschappelijk onderzoek en onderwijs draagt naar mijn mening zelf óók bij aan deze problematiek.

Wij dienen, met andere woorden, de hand in eigen boezem te steken. Om welke boezem gaat het?

Ten eerste om de verkokering van en tussen vakgebieden. Laat ik $u$ enkele voorbeelden daarvan geven.

We leren studenten in juridische faculteiten veel over het positieve recht, respectievelijk over leerstellingen en over interpretaties daarvan, maar nog relatief weinig over de werking en de gedragsgevolgen van regels en wetten, hoe mensen met contracten omgaan, of over de vraag welke cognitieve processen medebepalend zijn voor wat rechters in hun wijsheid beslissen. De oproep die Farnsworth (2007) aan juristen doet om meer ex-anteanalyses uit te voeren van de gevolgen voor derden van juridische constructies en uitspraken en daarbij te vertrekken vanuit kennis over gedragsmechanismen en mechanismen die op institutioneel niveau werkzaam zijn, wordt nog bij lange na niet overal serieus genomen.60 Gelukkig wel overigens aan déze universiteit, zoals onder andere blijkt uit de Master Forensica, waarin tal van disciplines effectief samenwerken (variërend van de criminologie, de rechtswetenschap en de rechtspsychologie tot DNA-onderzoek, de forensische accountancy en de empirische sociologie), maar ook uit initiatieven bij de Metajuridicagroep van de UM, waar meer aandacht de komende jaren zal uitgaan naar de werking van het recht, interdisciplinair beschouwd. ${ }^{61}$

Omgekeerd leren we studenten in de gedragswetenschappen nog vaak weinig over de aard en omvang van wet- en regelgeving en andere juridisch-institutionele arrangementen. Toch vormen zij vaak de restricties, respectievelijk opportuniteiten waaronder gedrag tot stand komt (vergelijk Coleman, 1990). Dat soort zaken 'hangen er vaak nog bij'.

Ik geef nog een derde voorbeeld van verkokering. Dat betreft de 
sociologie, mijn eigen vak. We leren sociologen onderzoek te doen naar sociaal kapitaal, relatievorming en - ontbinding en naar wederkerigheid versus conflicten, maar nog maar weinig wordt aandacht besteed aan neurobiologische oorzaken van dergelijke verschijnselen. Een recent voorbeeld laat Collins' nieuwe boek 'Violence, A Microsociological Theory' zien. In een recensie ervan in Nature van een paar maanden geleden, zetten Wilson en Daly (2008, p. 70) hem te kijk. 'Current knowledge in psychology, physiology and neuroscience is ignored. He also ignores a vast body of emotion research with direct implications for his theory.'

Voor veel criminologen geldt hetzelfde; hooguit met grote omzichtigheid hebben ze het incidenteel over neurobiologische en neuropsychologische oorzaken van antisociaal gedrag en nog veel schoorvoetender krijgen belangrijke variabelen uit die kennisvelden een plekje in hun eigen onderzoek. Zelfrapportage(metingen) en ander vragenlijstonderzoek overheersen, terwijl die vooral 'praatgedrag' registreren. Dat dit gemiste kansen creëert, laat een studie van De Kogel (2008) zien. Zij heeft de literatuur op dit gebied van de laatste tien tot vijftien jaar op een rij gezet en toont aan hoe sterk antisociaal gedrag verbonden is met neurobiologische en neuropsychologische mechanismen, en dat niet alleen bij psychopaten. Het gaat om kenmerken die geassocieerd zijn met de verwerking van informatie, het functioneren van het stresssysteem en de regulatie van het eigen gedrag en de eigen emoties. Het relatief nieuwe vakgebied, de social neuroscience, richt zich echter ook op de andere kant van de medaille, namelijk hoe het komt dat mensen zich wél kunnen verplaatsen in anderen, hoe sociale bindingen tot stand komen, en hoe vertrouwen tussen mensen opgewekt kan worden. Criminologische opleidingen waar dit gedachtegoed een meer dan marginale rol speelt in onderwijs en onderzoek, zijn er echter nog maar weinig. ${ }^{62}$

Het is dit silo-denken dat maakt dat het voor bestuurders, rechters en beleidsambtenaren ook vaak moeilijk is om bij het beantwoorden van de vraag of er geïntervenieerd moet worden en hoe dan, van geïntegreerde kennis gebruik te kunnen maken. Teulings (2008, p. 15) vatte het begin dit jaar aardig samen, toen hij in een beschouwing over wat we weten van de werking van markten het volgende schreef. 'Wetenschap is niet gebaat bij een kunstmatige gebiedsopdeling tussen economie, psychologie en recht. Twee theorieën over één verschijnsel zijn geen legitimatie voor intellectuele non-interventie, maar een uitdaging voor een overkoepelende theorie.' Wie nalaat een dergelijke overkoepeling te helpen realiseren, draagt ten eerste niet bij aan de groei van kennis, omdat overkoepelende theorieën overschotgehalte hebben ten opzichte 
van afzonderlijke theorieën, maar laat daarnaast 'decisionmakers' in de kou staan. ${ }^{63}$ Immers, het signaal is: 'zoek het zelf maar uit'.

Ik was bezig met de hand in eigen boezem te steken en ben daar nog niet mee klaar. Immers, ook het evaluatieonderzoek treft blaam. In Nederland in krap veertig jaar van niets tot veel gekomen, en dat is mooi en verdienstelijk (Leeuw, 2000; Leeuw, in druk). Samenlevingen hebben immers behoefte aan transparantie en tegenspraak, en dat is waar evaluatieonderzoek wel in voorziet. Wat mijn beroepsgenoten echter niet of te weinig doen, is naar gedragsmechanismen achter beleid speuren. Het gaat te vaak over hoe implementatieprocessen verlopen, wat de invoeringsproblemen zijn, en hoe het staat met de sociale acceptatie van interventies door belangengroepen. Dat helpt niet echt als je als bestuurder zicht wil krijgen op wat werkt en wat niet.

Eigenlijk geldt dat ook voor meta-analyses. Dat zijn studies waarin tientallen afzonderlijke evaluatieonderzoeken ten aanzien van een bepaalde set interventies worden beoordeeld, geclassificeerd en tot conclusies over de effectiviteit van interventies worden gebracht. Voorbeelden zijn meta-analyses van tientallen evaluaties van maatregelen om je huis beter te beveiligen, drop-outgedrag op scholen te voorkomen, mensen aan te zetten meer of juist minder kinderen te krijgen, of minder vet en meer groente te eten. Aardig allemaal en belangrijk, zeker als je alleen wil weten of een bepaalde interventie 'zutrifft', maar beter ware het niet alleen dit type kennis te verzamelen, maar ook te speuren naar kennis over de werking van gedragsmechanismen achter beleidsmaatregelen. Dat gebeurt in het evaluatieonderzoek nog veel te weinig. De Britse socioloog Ray Pawson (2006)64 werkt wel op zo'n manier en dat bevalt goed. Hij speurde onlangs naar de gedragsmechanismen die achter tientallen in het Verenigd Koninkrijk ingevoerde naming, shaming and blaming-interventies steken en die op totaal verschillende beleidsvelden betrekking hebben. De velden variëren van enerzijds programma's om veroordeelde maar inmiddels afgestrafte en vrijgekomen pedoseksuelen via posters, radio-uitzendingen en bulletin boards zodanig veel angst aan te jagen, dat ze niet meer durven te recidiveren, tot anderzijds het bepaalde Britse kroegbazen zoveel reputatieschade toe te brengen, dat ze binge drinking (coma-drinken) niet meer in hun cafés toestaan. Pawson onderzoekt of schandpaalgedrag werkt, onder welke condities, voor hoe lang en met welke neveneffecten. Hij speurt naar middle range gedragstheorieën, die demi-regs opleveren. Demi-regs staan voor demi-regularities, gedeeltelijke wetmatigheden die niet aan specifieke beleidsinterventies of rechtsregels verbonden zijn, maar daarom 
dés te belangrijker zijn. ${ }^{65}$

\section{Slotwoord}

Dames en heren, de tijd is op.

Jonge hoogleraren hebben, bij het slot van hun openbare les aangekomen, de neiging om tal van concrete projecten te noemen waar ze zich op gaan richten. Daar hoeft $u$ vandaag niet bang voor te zijn. Ik deed zoiets al een beetje in mijn Utrechtse oratie, vijftien jaar geleden. Het zijn beginnersfouten. Maar tegelijkertijd zal het $u$ wel duidelijk zijn waar ik mij in mijn Maastrichtse jaren op wil richten. Dat is op gedragsmechanismen achter de plethora van interventies en rechtsregels, op béter evaluatieonderzoek en op effectievere syntheses van onderzoeksbevindingen en theorieën ten behoeve van onderzoek van - vooral ook - juridische vragen. Ook is onderzoek naar onderwijs-, arbeids- en criminele loopbanen, samen met het ROA, het CBS en het WODC in voorbereiding.

Jonge hoogleraren eindigen hun oratie doorgaans óók met het bedanken van hemel en aarde voor het feit dat ze hier staan. Ook dit zijn in zekere zin beginnersfouten. Ik hou mijn dankwoord dus kort.

In de eerste plaats wil ik het College van Bestuur en het Bestuur van de Faculteit der Rechtsgeleerdheid van deze universiteit bedanken voor het in mij gestelde vertrouwen. Het is een prachtige stoel op een prachtige plek aan een fraaie universiteit. Ik dank ook de besturen, collega's en studenten van verschillende faculteiten met wie ik de afgelopen twee jaar heb samengewerkt. Ik zie uit naar meer.

De combinatie van de leerstoel met mijn werk bij het Haagse WODC is een win-winsituatie, waarvoor ik mijn collega's eveneens dankzeg.

Reinhard Wippler en Wout Ultee beschouw ik, naast mijn helaas overleden Leidse promotor Mark van de Vall als mijn belangrijkste leermeesters. Ook veel dank aan hen.

$\mathrm{Pa}$ en $\mathrm{Ma}$, dik in de tachtig, zijn hier. Dat is fijn! En dank voor alle support vele jaren lang.

Jasper, Bastiaan en Marijke, jullie zijn mijn 'working mechanisms'. De besten en de liefsten.

Ik heb gezegd. 


\section{Literatuur}

Algemene Rekenkamer, Verslag van de Algemene Rekenkamer over 1994, Deel 3: Zelfstandige bestuursorganen en ministeriële verantwoordelijkheid, 1995, Kamerstukken I/ 1994/95, 24 130, nr. 3.

Algemene Rekenkamer, Verantwoording en toezicht bij rechtspersonen met een wettelijke taak, Deel 4, 2004, Kamerstukken II 2003/04, 29 450, nr. 1-2.

Arts, W.A., S. Lindenberg \& R. Wippler, Gedrag en structuur, Boekuitgave Mens en Maatschappij, Universitaire Pers Rotterdam, Rotterdam, 1976.

Axelrod, R., The Evolution of Cooperation, Basic Books, New York, 1984.

Bandura, A., Social Foundations of Thought and Action: A Social Cognitive Theory, Prentice-Hall, Englewood Cliffs, NJ, 1986.

Barendrecht, M. et al. (red), Balanceren en vernieuwen. Een kaart van sociaalwetenschappelijke kennis voor de fundamentele herbezinning procesrecht, Raad voor de Rechtspraak, Den Haag, 2004.

Beus, J.W. de \& J.A.A. van Doorn (red.), De interventiestaat, Boom, Meppel, 1984.

Bijnen, R.H.J. van, Aanvullend contractenrecht, Boom Juridische uitgevers, Den Haag, 2005.

Bokhorst, A.M. \& F.J.van Ommeren, Regeldruk ontrafeld, in: Nederlands Juristenblad (NJB), 82 (2007): 682-686.

Boom, W.H. van de, Structurele fouten in het aansprakelijkheidsrecht, Oratie, Universiteit van Tilburg, Boom Juridische uitgevers, Den Haag, 2003.

Boom, W.H. van, Effectuerend handhaven in het privaatrecht, in: Nederlands Juristenblad (NJB), 82 (2007): 982-991.

Boom, W.H. van, I. Giesen \& A.J. Verheij (red.), Gedrag en privaatrecht. Over gedragspresumpties en gedragseffecten bij privaatrechtelijke leerstukken, Boom Juridische uitgevers, Den Haag, 2008.

Buchanan, Mark, The Social Atom: Why the Rich Get Richer, Cheaters Get Caught, and Your Neighbour Usually Looks like You, Bloomsbury, New York, 2007.

Bunge, Mario, How Does it Work?, The Search for Explanatory Mechanisms, in: Philosophy of the Social Sciences, 34 (2004):182-210.

Bunt, H.G. van de, Aan het eind van de keten: de strafexecutie stiefmoederlijk bedeeld, in: Justitiële Verkenningen, 26 (2000): 10-18.

Chrystal, K. \& P. Mizen, Goodhart's Law: Its Origins, Meaning and Implications for Monetary Policy, Prepared for the Festschrift in honour of Charles Goodhart to be held on 15-16 November 2001 at the Bank of England, November 12, 2001.

Cliteur, P.B., Nederlands recht, Kluwer, Deventer, 2005.

Coleman, James, Foundations of Social Theory, Bellknap Press, Cambridge, 1990.

Croes, M.T., Naar een bruikbare rechtsorde; bijdragen uit de sociale wetenschap, Cahier 2007-12, WODC, Den Haag, 2007.

Daudt, H., De politieke toekomst van de verzorgingsstaat, in: J.A.A. van Doorn \& C.J.M. Schuyt (red.), De stagnerende verzorgingsstaat, Boom, Meppel, 1978: 189-221.

Dawson, John, Regulation and the Macroeconomy, in: Kyklos, 60 (2007): 15-36.

Doorn, J.A.A. van \& C.J.M. Schuyt (red.), De stagnerende verzorgingsstaat, Boom, Meppel, 1978. 
Downs, Anthony, An Economic Theory of Democracy, Addison Wesley Publishing Company, Harper,1957.

Downs, Anthony, Inside Bureaucracy, A Rand Corporation Research Study, Little, Brown, and Company, Boston, 1967.

Egas, M. \& A. Riedl, The Economics of Altruistic Punishment and the Maintenance of Cooperation, in: Proceedings of the Royal Society of London/Biological Sciences, 275 (2008): 871-878.

Elster, Jon, Nuts and Bolts for the Social Sciences, Cambridge University Press, Cambridge, 1989.

Elster, Jon, Explaining Social Behavior: More Nuts and Bolts for the Social Sciences, Cambridge University Press, Cambridge, 2007.

Farnsworth, W., The Legal Analyst. A Toolkit for Thinking about the Law, University of Chicago Press, Chicago, 2007.

Frissen, P.H.A., De staat van verschil. Een kritiek van de gelijkheid, Van Gennep, Amsterdam, 2007.

Frumkin, P. \& J. Galaskiewicz, Institutional Isomorphism and Public Sector Organizations, in: Journal of Public Administration Research and Theory, 3 (2004): 283-307.

Geelhoed, L.A., De interveniërende staat, Den Haag, 1983.

Genn, Hazel, Martin Partington \& Sally Wheeler, Law in the Real World: Improving Our Understanding of How Law Works, Nuffield Foundation, London, 2006.

Gestel, R. van \& M. Hertogh, Wat is regeldruk? Een verkennende internationale literatuurstudie, WODC, Boom Juridische uitgevers, Den Haag, 2006.

Giesen, I., Alternatieve regelgeving in privaatrechtelijke verhoudingen, in: Preadviezen, Handelingen Nederlandse Juristen-Vereniging, 137e jaargang, 2007-1: 67-169.

Gijsberts, Mérove en Jaco Dagevos (red.), Interventies voor integratie, SCP, Den Haag, 2007.

Griffith, J., De sociale werking van het recht: een kennismaking met de rechtssociologie en rechtsantropologie, Ars Aequi Libri, Amsterdam, 1996.

Hartendorp, R.C., Praktisch gesproken. Alledaagse civiele rechtspleging als praktische oordeelsvorming, Dissertatie Erasmus Universiteit Rotterdam, Rotterdam, 2008.

Hedström, P. \& R. Swedberg (red.), Social Mechanisms. An Analytical Approach to Social Theory, Cambridge University Press, Cambridge, 1998.

Heide, Wieger van der, Frank van Tulder \& Cas Wiebrens, Strafrechter en strafketen: de gang van zaken, 1995-2006, in: Rechtstreeks, 3 (2007): 7-72.

Hirsch Ballin, E., Netwerken van rechtsontwikkeling, Preadvies voor de Vergadering van de Christen Juristen Vereniging op 7 mei 1999, Lemma, Utrecht, 1999.

Huls, N., Actie en reactie. Een inleiding in de rechtssociologie, Boom Juridische uitgevers, Den Haag, 2008.

Hülsmann, J.G., Mises. The Last Knight of Liberalism, Ludwig von Mises Institute, Auburn, 2007.

Jong, P.O. de en M. Herweijer, Alle regels tellen, Boom Juridische uitgeverij, Den Haag, 2004. 
Jongeneel, C., Verzelfstandiging: stijl of trend? De stijlen van verzelfstandiging van de beleidssectoren van de Rijksoverheid; en hun consistentie met de institutionele context, Scriptie Bestuurskunde Erasmus Universiteit Rotterdam, 2005.

Kemp, A.J. de, W. van Dam, W. van der Mei, O. Delsman \& F.L. Leeuw, Subsidies en overheidsbeleid, in: Beleidswetenschap, 3 (1989): 203-219.

Kleemans, Edward, Carolien Klein Haarhuis, Frans Leeuw \& Marianne van Ooyen-Houben, Law Enforcement Interventions in the Netherlands: Mapping Interventions and 'Browsing' for Evidence, in: Evidence \& Policy, 4 (2007): 487-504.

Klein Haarhuis, C.M. \& E. Niemeijer, Wet en werkelijkheid. Bevindingen uit evaluaties van wetten, WODC, Boom Juridische uitgevers, Den Haag, 2008.

Knaap, L.M. van der, L.T.J. Nijssen \& S. Bogaerts, Geweld verslagen? Een studie naar de preventie van geweld in het publieke en semi-publieke domein, Boom Juridische uitgevers, Den Haag, 2006.

Knaap, L.M. van der, Frans Leeuw, Stefan Bogaerts \& Laura Nijssen, Combining Campbell Standards and the Realist Evaluation Approach. The Best of Two Worlds, in: American Journal of Evaluation, 29 (2008): 48-57.

Kogel, C.H. de, De hersenen in beeld. Neurobiologisch onderzoek en vraagstukken op het gebied van verklaring, reductie en preventie van criminaliteit, WODC, Boom Juridische uitgevers, 2008.

Kogel, C.H. de \& M.H. Nagtegaal, Toezichtprogramma's voor delinquenten en forensisch psychiatrische patiënten. Effectiviteit en veronderstelde werkzame mechanismen, WODC, Boom Juridische uitgevers, Den Haag, 2008.

Koopmans, T. De rol van de wetgever, in: Honderd jaar rechtsleven, Tjeenk Willink, Zwolle, 1970: 1-15.

Kulu Glasgow, I., F.L. Leeuw, E. Uiters, R.V. Bijl, Integratiebeleid rijksoverheid onderzocht: een synthese van resultaten uit evaluatie- en monitoringonderzoek 2003-2006. Cahier 2007-3, Den Haag: WODC.

Kuran, Timur \& Sunstein, Cass R., Availability Cascades and Risk Regulation, in: Stanford Law Review, 51 (1998-1999): 683-769.

Lam, V.M.Y. van 't \& R. Uylenburg, Modernisering van VROM pseudowetgeving, STEM publicatie 2005/6, Arnhem, 2006.

Lawson, T., Economics and Reality, Routledge, Londen, 1997.

Leeuw, Frans L., Doelmatigheidsonderzoek bij de Algemene Rekenkamer: ontwikkelingen in de afgelopen tien jaar en schetsen voor de toekomst, in: Bestuurswetenschappen, 46 (1992): 8-25.

Leeuw, Frans L., Evaluatieonderzoek, auditing en controle in Nederland anno 2000, in: T. Abma \& Roel J. in 't Veld (red.), Handboek beleidswetenschap, Boom, Amsterdam, 2001: 70-83.

Leeuw, Frans L., Trends and Developments in Program Evaluation in General and Criminal Justice Programs in Particular, in: European Journal on Criminal Policy and Research, 11 (2005): 18-35.

Leeuw, Frans L., On the Contemporary History of Experimental Evaluations and Its Relevance for Policy Making, in: Tom Ling et al. (red.), The Evidence Movement, Transaction Publishers, Rutgers, London, in druk. 
Leeuw, Frans L. \& Willemien de Jongste, Beleids- en wetsevaluaties: trends en topics, in: Regelmaat, 14 (2006): 83-95.

Leeuw, Frans L. \& Marian Hulshof, Overheidsinterventies en onderwijs: kennis over gedragsmechanismen als wenkend perspectief? In: Onderwijsraad, Essays over beleidsinstrumenten in het onderwijs, Den Haag, 2007: 87-100.

Leeuw, Frans L. et al., Reducing the Knowledge-Practice Gap: A New Method Applied to Crime Prevention, in: Public Money \& Management, 12 (2007): 245-251.

Light, Paul C., The Tides of Reform: Making Government Work, 1945-1995, Yale University Press, New Haven \& London, 1997.

Light, Paul C., The Tides of Reform Revisited: Patterns in Making Government Work, 1945-2002, in: Public Administration Review 66 (2006): 6-19.

Loonen, A.J.M., Juridisch bewijs gezien door een biomedische wetenschapper, in: Nederlands Juristenblad (NJB), 83 (2008): 158-160.

Mayntz, R., Mechanisms in the Analysis of Social Macro-Phenomena, in: Philosophy of the Social Sciences, 34 (2004): 237-259.

Michiels, F.C.M.A., Houdbaar handhavingsrecht, Oratie, Universiteit van Tilburg, Kluwer, Deventer, 2006.

Michiels, F.C.M.A., Te kijk gezet, Ministerie van Verkeer en Waterstaat, Den Haag, 2007.

Ministerie van Financiën, www.minfin.nl, 2005 (overzicht aantal agentschappen).

Mises, L. von, Kritik des Interventionismus, Wissenschaftliche Buchgesellschaft, Darmstadt, 1976 (eerste druk 1929, Gustav Fischer Verlag) (vertaald als: A Critique of Interventionism; Inquiries into Present Day Economic Policy and Ideology, Gustav Fischer, Jena, 1929).

Mises,L. von, Die Wahrheit über den Interventionismus, in: Monatsblätter für freiheitliche Wirtschaftspolitik, 3 (1957): 599-607

Mueller, Dennis, Public Choice III, Cambridge University Press, Cambridge, 2003. Onderwijsraad, Veelzeggende instrumenten van onderwijsbeleid, Den Haag, 2007. Pawson, R., Evidence Based Policy: A Realist Perspective, Sage, London, 2006.

Poort, R. \& K. Eppink, Het beleid van de reclassering, theoretische onderbouwing van, visie en werkzaamheden van de reclassering. Rapportage ten behoeve van de Adviescommissie Onderzoeksprogrammering Reclassering, Ministerie van Justitie, in druk.

Posner, Richard A., The Role of the Judge in the Twenty-first Century, in: Boston University Law Review, 86 (2006): 1049-1069.

Rachlinski, J.J., The Psychology of Conflict of Laws, in: Jan Smits (red.), The Need for a European Contract Law. Empirical and Legal Perspectives, Europe Law Publishing, Groningen, 2005: 96-123.

Riedl, A., Facts and Fiction in Public Economics, How Behavioural and Experimental Economics Can Inform Public Policy, Oratie, Universiteit Maastricht, Maastricht, 2006.

Rijpkema, Peter, Rechtersrecht, Boom Juridische uitgevers, Den Haag, 2001.

Rooks, G. et al., How Inter-firm Co-operation Depends on Social Embeddedness: A Vignette Study, in: Acta Sociologica, 43 (2000): 123-137. 
Schuyt, C.J.M, Het rechtskarakter van de verzorgingsstaat, in: J.A.A. van Doorn \& C.J.M. Schuyt (red.), De stagnerende verzorgingsstaat, Boom, Meppel, 1978: 73-97.

Scott, W. Richard, Organizations. Rational, Natural, and Open Systems, Prentice Hall, Upper Saddle River, 2003.

Stuphorn, V., Neuroeconomics: The Shadow of the Future, in: Current Biology, 15 (2005): R247-R249.

Sunstein, Cass R., Introduction. In: Cass R. Sunstein (red), Behavioral Law \& Economics, Cambridge University Press, Cambridge, 2000.

Suurmond, G. \& B.C.J. van Velthoven, Werkt gevangenisstraf echt niet? Criminologen als struisvogels, in: Justitiële Verkenningen, 34 (2008): 27-46.

Teulings, Coen, Markt en moraal gaan hand in hand, alleen aan jezelf denken loont niet in de evolutie, Nrc Handelsblad, 2 februari 2008.

Thiel, Sandra van, The 'Empty Nest' Syndrome: Dutch Ministries after the Separation of Policy and Administration, Paper for the panel Government at arms' length: the pendulum shift? IRSPM 12 Conference, Brisbane, Australia, 26-28 March 2008.

Thiel, S. van \& M.W. van Buuren, Ontwikkeling van het aantal zelfstandige bestuursorganen tussen 1993 en 2000: zijn zbo's 'uit' de mode? In: Bestuurswetenschappen, 5 (2001), 386-404.

Tilley, N., Realistic Evaluation and Disciplinary Knowledge: Applications from the Field of Criminology, in: Jos Vaessen \& Frans L. Leeuw (red.), Evaluation and the Disciplines, Transaction Publishers, New Brunswick and London,in druk.

Ultee, W.C., Groei van kennis en stagnatie in de sociologie, Dissertatie Universiteit Utrecht, Utrecht, 1977.

Ultee, W.C., Minder misdrijven: door overheidsingrijpen of zelfbescherming, in: Justitiële Verkenningen, 8 (2008): 46-57.

Ultee, W. C. Arts \& H. Flap, Sociologie - vragen, uitspraken, bevindingen, WoltersNoordhoff, Groningen, 2003.

Veerman, Gert-Jan, Irrational People, Rational Legislation, Paper, Workshop 'Legisprudence', 23rd IVR Congress, Cracow, 1-6 August, $2007 \mathrm{.}$.

Veerman, G.J., Over wetgeving; principes, paradoxen en praktische beschouwingen, SDU Uitgeverij, Den Haag, 2007b.

Vellinga-Schootstra, F., Strafrechtersrecht: rechtersregelingen in het strafproces, in: B.F. Keulen, G.Knigge \& H.D. Wolswijk (red.), Liber amicorum D.H. de Jong, Wolf Legal Publishers, Nijmegen, 2007: 493-516.

Weaver, C. et al., Epigenetic Programming by Maternal Behaviour, in: Nature Neuroscience, 7 (2004): 847-854.

Willemsen, Frank, Frans Leeuw \& Bastiaan Leeuw, Toezicht en inspectie in maten en soorten, in: Tijdschrift voor Criminologie, 50 (2008): in druk.

Wilson, James O., Bureaucracy: What Government Agencies Do and Why They Do It, Basic Books, New York, 1989.

Wilson, M. \& M. Daly, A Close Look at Conflict, in: Nature, 451 (2008): 769-770.

Wippler R., The Structural-Individualistic Approach in Dutch Sociology, in: The Netherlands Journal of Sociology, 14 (1978): 135-155. 
Witteveen, W.J., Alternatieve regulering, de vele gezichten van de wetgever, in: Handelingen Nederlandse Juristen-Vereniging, 137, 2007-1: 1-67.

Witteveen, W.J., \& J.L.M. Gribnau, Maatschappelijke rechtsvorming, in: Maatschappelijke rechtsvorming, Boom Juridische uitgevers, Den Haag, 2005: 1-6.

Zaalberg, A. Effecten van voedingssupplementen op agressie, regelschendend gedrag en psychische klachten van jongvolwassen Nederlandse gedetineerden: Eerste resultaten van een gerandomiseerd placebo-gecontroleerd onderzoek in acht Nederlandse Penitentiaire Inrichtingen, Werkdocument DJI, Ministerie van Justitie \& Radboud Universiteit Nijmegen, 2007. 


\section{Referenties}

1 Met dank aan Marnix Croes (WODC en Raad voor de rechtspraak), Jaap Hage (Universiteit Maastricht), Willemien de Jongste (WODC), Ger van Gils (BOA), Rianne de Klerk (Boom Juridische Uitgeverij) en Bastiaan Leeuw voor commentaar op een eerdere versie.

2 Von Mises richtte zich vooral op fiscale en economische interventies, maar hij besteedde ook aandacht aan sociaal beleid, zoals 'die Kürzung der Arbeitszeit, Zwangsversicherung der Arbeiter auf Kosten der Unternehmer, Vorschriften über die Einrichtung der Betriebe, Urlaub der Arbeiter bei Fortbezug des Lohnes u. dgl. m.' (Von Mises, 1976, p. 34). Zie ook: von Mises (1957).

3 Vgl. onder andere J.W. de Beus en J.A.A. van Doorn (1984), J.A.A. van Doorn en C.J.M. Schuyt (1978) en L.A. Geelhoed (1983).

4 Overigens wees In 't Veld in zijn afscheidsrede aan de toenmalige Katholieke Universiteit Nijmegen, getiteld 'Verandering en bestuur. Een pleidooi voor een bescheiden bestuurskunde', Nijmegen, 1982, ook op het fenomeen van de beleidsaccumulatie. 'Steeds meer wordt binnen de politieke sector getrokken vanwege de wenselijkheid van beheersing. Integratie lijkt echter zelden te lukken, terwijl meer beleid geenszins onbedoelde zijdelingse effecten voorkomt, maar integendeel uitlokt' (p. 13 en 14). Enige jaren later vulde hij zijn redenering aan met de wet van de afnemende effectiviteit van beleid.

5 Dat maakte dat ook een andere belangrijke redenering, Goodhart's law, evenmin gerecipieerd werd. Charles Goodhart formuleerde de uitspraak dat als overheden op basis van waargenomen statistische regelmatigheden beleidsmaatregelen invoeren, deze regelmatigheden daardoor onder druk komen te staan en uiteindelijk zelfs verdwijnen. Het gevolg is dat de ingevoerde beleidsmaatregelen ineffectief worden (Chrystal \& Mizen, 2001). In de Nederlandstalige literatuur over de verzorgingsstaat (zie noot 3) werd weinig aan werk van economen gerefereerd, met als uitzondering Keynes. Incidenteel werden ook Nederlandse economen, zoals Van den Doel, Heertje, Pen en Wolfson, genoemd, maar zij leggen het af tegen (Nederlandse) -ologen en -kundigen. Daudt (1978) verwijst overigens wel een keer naar Von Mises en naar Downs (vgl. p. 190 en 208).

6 Zie bijv. Hayek's 'The Road to Serfdom', dat in 1944 in de VS verscheen en waarover hij met Von Mises discussieerde, zoals in Hülsmanns (2007) biografie van Von Mises te lezen is.

7 In 1974 ontving Hayek de Nobelprijs voor economie.

8 In deze oratie bedoel ik daar waar ik over overheid spreek, grosso modo de rijksoverheid en met haar verbonden (zelfstandige) bestuursorganen.

9 Vgl. De Commissie Geelhoed, Tussenbericht, Handelingen II 1983/84, 17 931, nr. 3. Het eindrapport betreft nr. 9 .

10 In de Nota Modernisering Rijksoverheid van september 2007 is het volgende te lezen. 'Het vertrouwensprincipe indachtig wordt dan ook een drastische reductie van het 
toezicht doorgevoerd. De taakstellingen in deze gebieden zitten tussen de 20 en de $30 \%$ van het huidige aantal functies' (p. 11). Het is interessant te zien dat de analyse van de noodzaak van reductie wel wijst op zaken als de onhaalbaarheid om beleid te laten voldoen aan 'gelijkheid' (in behandeling) en voorspelbaarheid enerzijds en maatwerk anderzijds, en ook op 'nodeloos ingewikkelde verfijningen', maar dat het thema dat het kernpunt van deze oratie is (de problematiek rondom gedragsmechanismen), níet aan de orde komt. " 'Like rules breed rules', een uitspraak waar Van Gestel en Hertogh (2006, p. 112) naar verwijzen, maar die zij op grond van door hen geïnventariseerde studies onderuithalen. 12 Afkomstig uit de Dreigroschenoper, die op 31 augustus 1928 in Berlijn voor het eerst vertoond werd. Met dank aan Menno Bouwes van de Directie Wetgeving van het ministerie van Justitie voor het citaat.

$13 \mathrm{Er}$ is geen ruimte om een counterfactual-analyse uit te voeren naar wat er gebeurd zou zijn met de hoeveelheid recht, regelgeving en andere bestuurs- en beleidsinterventies, als deze operaties er niet waren geweest.

14 Vgl. Klein Haarhuis en Niemeijer (2008).

15 Inclusief begrotingswetten en intrekkingen, die ook bij wet geschieden. Naar aanleiding van het onderzoek van De Jong en Herweijer ontspon zich een debat over hoeveel 'Europees' is aan deze regelgeving. Zie M.A.P. Bovens en K. Yesilkagit, De invloed van Europese richtlijnen op de Nederlandse wetgever, in: NJB, 11 maart 2005, afl. 10.

16 Op 'wetgeving door ambtenaren', zoals Huls (2008, p. 123 e.v.) het noemde (in 1969 door Crince le Roy met de de term 'vierde macht' aangeduid), ga ik niet in. Voor het telwerk maakt dat namelijk niet uit.

17 Het gaat hier om overheidsstichtingen (door, mede of namens de overheid opgericht), waarbij gedacht kan worden aan organisaties zoals 'vrienden van het Rijksmuseum' of 'veteranenverenigingen'. Het ministerie van Financiën heeft enkele jaren geleden een lijst met ca. 330 stichtingen gepresenteerd.

18 Opvallend dat economen daar wel veel aandacht aan besteden. Zie bijv. Suurmond en Van Velthoven (2008), maar ook socioloog Ultee (2008). Suurmond en Van Velthoven (2008) spreken over struisvogelpolitiek van criminologen die geen oog willen hebben voor de criminaliteitsafremmende effecten van gevangenisstraf, en onderbouwen die stelling met onderzoeksresultaten van economen. Ultee (2008) laat zien welke (verklarings)vragen blijven liggen.

19 Dienst Justitiële Inrichtingen (DJI). 'De reclassering' wordt gevormd door Reclassering Nederland en de reclasseringsafdelingen van het Leger des Heils en de GGZ.

20 Soms wordt wel over 'ordeningswet- en regelgeving' gesproken om aan te geven wat de achtergrond van deze vorm van interventionisme is.

${ }_{21}$ Michiels (2007) presenteerde ook een studie over naming \& shaming-interventies van het ministerie van Verkeer en Waterstaat. Hij analyseert weliswaar vooral wet- en regelgevingteksten, maar vraagt soms ook aandacht voor gedragskanten van deze interventies. Daar bijvoorbeeld waar het de waarschuwing aan een bedrijf betreft, die van 
openbaarmaking beoogt uit te gaan, maar welke waarschuwing in de praktijk 'de facto een sanctionerend karakter kan hebben' (p. 52). Een andere relevante zinsnede is op p. 60 aan te treffen. 'De tot nu toe gewezen jurisprudentie op het terrein van het markttoezicht neemt al snel aan dat er geen sanctie is, wanneer de primaire bedoeling van de publicatie waarschuwing van het publiek is.' Het is zonneklaar dat wat beoogd wordt te zijn, in de sociale werkelijkheid ánders kan uitpakken.

22 Deze cijfers zijn deels afkomstig uit een monitor van het Expertisecentrum Rechtshandhaving en uit jaarverslagen. Zie Willemsen, Leeuw en Leeuw (in druk). 23 Een paar voorbeelden over 2006: verbeurdverklaringen (29.000 x), pluk-ze-sanctie (1000 x), 200.000 boetevonnissen, enkele tienduizenden taakstraffen-volwassenen, ca. 20.000 taakstraffen-minderjarigen enz. Zie verder: Van der Heide, Van Tulder \& Wiebrens, 2007.

24 Een en ander is gebaseerd op de brief van 27 februari 2006 van de minister van Financiën aan de Tweede Kamer (Kamerstukken II 2005/06, 30300 IXB), waarin op de achtergronden van het IOR wordt ingegaan en per departement een overzicht van subsidies/regelingen wordt gegeven. Het onderstaande is daarop gebaseerd. 'Bij de samenstelling van het IOR zijn de volgende uitgangspunten gehanteerd:

- Het IOR is een overzicht van alle uitgaande geldstromen van departementen;

- Alleen eerste geldstromen zijn in het overzicht opgenomen;

- De instrumenten zijn gecategoriseerd volgens het Europees Stelsel van Rekeningen (ESR) en ingedeeld naar bijbehorende ESR-codes;

- Voor bepaalde specifieke geldstromen is aanvullende informatie geleverd, dit betreffen de subsidies, sociale uitkeringen en overdrachten (in het vervolg subsidies en overdrachten genoemd). Het totale IOR omvat alle uitgaande geldstromen van het Rijk binnen één jaar (stand ontwerpbegroting 2006). Het betreft een bedrag van 149,4 miljard euro, verdeeld over 983 instrumenten. Het IOR is tot stand gekomen op grond van een motie van het Kamerlid Van As in 2003. Dat heeft geresulteerd in een interdepartementale werkgroep die het rapport «Zicht op subsidies» heeft voortgebracht. Het doel van deze werkgroep was tweeledig: als eerste het maken van een inventarisatie van de toenmalige departementale subsidies en ten tweede het opstellen van een beoordelingskader voor subsidies. In het najaar van 2003 heeft de minister van Financiën in een debat over het rapport Zicht op Subsidies met de Kamer afgesproken dat eens in de vier jaar (voorafgaand aan het jaar van een kabinetsformatie) een breed overzicht van en inzicht in subsidies zal worden opgesteld,' Overigens gaat dit overzicht terug op het rijksbrede doelmatigheidsonderzoek van de Algemene Rekenkamer uit 1988, waarin, voor het eerst, alle rijkssubsidies geteld werden (De Kemp et al., 1989). Zie: http://rijksbegroting.minfin. nl/rijksbegroting_nl/coe23470bf494825b71251cfc75d3e25×63×39368xo2.php?cycl=2006\&f ase $=\mathrm{mn} \&$ hfds $=40.7 \& \mathrm{it}=\mathrm{B} \&$ usetemplate $=078545$ a $074 \mathrm{~d} 2 \mathrm{ebgf6fb} 3 \mathrm{ecd} 3 \mathrm{cogd} 1281$.

25 In het artikel dat de auteurs over dit Rekenkameronderzoek schreven, werd aangegeven dat het in 1970 nog om ca. 4,8 miljard gulden aan jaarlijkse subsidie-uitgaven ging. 
26 De goede verstaander kan denken dat ik dit woord gebruik in lijn met Griffith's studie naar de relatie tussen quasi-autonome sociale velden én de werking van wet- en regelgeving (Griffith, 1996). Dat is correct.

27 PIJ staat voor 'plaatsing in een inrichting voor jeugdigen'. Deze maatregel staat ook wel bekend als jeugd-tbs, maar beide maatregelen zijn niet volledig vergelijkbaar (Van der Heide, Van Tulder \& Wiebrens, 2007, p. 50).

28 Ook wordt er geëxperimenteerd met voedselsupplementinterventies (omega 3) binnen het gevangeniswezen omdat daar heilzame effecten van bekend zijn op (reductie van) geweld tussen gedetineerden (Zaalberg, 2007).

29 Sinds enige tijd wordt niet langer over tbs-klinieken gesproken maar over 'forensischpsychiatrische centra' (fpc's).

$30 \mathrm{Vgl}$. Poort en Eppink (in voorbereiding). Zie ook de Kogel en Nagtegaal (2008).

31 De Erkenningscommissie heeft als opdracht het ex ante beoordelen of gedragsinterventies kunnen leiden tot vermindering of het voorkomen van recidive van de deelnemers. De commissie heeft drie taken, te weten: het beoordelen van gedragsinterventies, het adviseren over de effectiviteit van gedragsinterventies aan de minister van Justitie en het communiceren over haar activiteiten.

32 Het Lindenbaum-Cohen-arrest van de Hoge Raad zou beschouwd kunnen worden als het begin van het 'privaatrechtelijk rechtersrecht', zoals WODC-collega mr. Willemien de Jongste het zei. Het arrest gaf een ruimere betekenis aan het begrip onrechtmatige daad, omdat sinds dit arrest iets als een onrechtmatige daad kon worden aangemerkt als het handelingen betrof die indruisten tegen de zorgvuldigheid die men in het maatschappelijk verkeer tegen andermans goederen moest hebben. Vgl. ook Cliteur (2005) en Rijpkema (2001).

33 Voorbeelden zijn rechtersregelingen ('een op schrift gestelde algemene regel dan wel een complex van zulke regelingen, die is vastgesteld door een of meer rechters, anders dan in de vorm van een beslissing in een concrete zaak, en die betrekking heeft op de invulling van een bepaalde vorm van beslissingsruimte die de rechter heeft ten aanzien van de behandeling of beslissing van zaken' (Giesen, 2007, p. 85). Giesen inventariseert er ook bij scheiding- en alimentatieprocedures, dagvaarding in rolzaken sector civiel, conservatoir beslag, liquidatietarieven, schuldsanering, ontslag enz. (p. 85) en bij medische protocollen. 34 In de literatuur is al langere tijd een debat gaande over de vraag wat maatschappelijk gezien doelmatiger is, common law of civil law. Deels gaat het over de vraag of common law meer tot spontane ordeningen in termen zoals omschreven door Hayek leidt dan civil law.

35 Zie ook de bundel over privaatrecht en gedrag die onder redactie van W.H. van Boom, I. Giesen en A.J. Verheij (2008) tot stand kwam.

36 'Civil law and justice is not a coherent field or concept. There is no 'civilology' equivalent to criminology. The sheer breadth and diversity of civil justice issues - spanning family, administrative justice, commercial, employment, property, contract etc - may inhibit the 
creation of a critical mass of researchers in any one subject area, which in turn slows down the development' (Genn et al, 2006:4).

37 Deze ontwikkeling vindt Giesen (2007, p. 127) zo belangrijk dat hij een pleidooi houdt voor een POR, een Periodiek Overleg van Rechtsvormers.

38 Witteveen geeft als één van de manieren hoe richtlijnen binnen - bijvoorbeeld - de medische wereld door kunnen dringen in de rechterswereld, het volgende aan. 'Als de rechter bij de invulling van de uit de wet afgeleide open norm van het zijn van een goed hulpverlener de inhoud van het protocol betrekt bij de vraag of in overeenstemming met geldende medische standaarden is gehandeld, wordt de zelfregulering binnen de beroepsgroep maatschappelijk relevant gemaakt' (p. 37). Hij formuleert ook een tip voor empirisch onderzoek naar deze wijze van regulering. Ten aanzien van het strafrecht(ersrecht) doet hij de suggestie de straftoemetingsbulletins van Trema te analyseren om vast te stellen hoe strafrechters kennisnemen van wat zich elders aan - in dit geval het strafrecht - oriëntatiepunten voor de straftoemeting voordoet. Hij doet vergelijkbare suggesties voor andere rechtsgebieden (Witteveen, 2007, p. 38).

39 Weliswaar uit een wetenschapstheoretisch gezien geheel ándere hoek (de hermeneutische) snijdt Hartendorp (2008, p. 103) een vergelijkbaar thema aan. 'In de door mij verzamelde casussen wordt door rechters nauwelijks over toepassings- of interpretatieproblemen gesproken. Rechtsvragen, de wijze waarop het recht moet worden toegepast, komen in de meeste casussen die eerstelijnsrechters behandelen nauwelijks expliciet aan de orde. Het merendeel van de tijd en aandacht wordt besteed aan de feitenvaststelling en de bewijslevering. Wat is er feitelijk voorgevallen? Wat moet nog worden bewezen? Rechters lijken min of meer een spontaan begrip van (de toepassing van) het recht te hebben.'

40 Evenmin is bekend hoeveel strafrechtersrecht er is (vgl. ook Vellinga-Schootstra, 2007).

41 Zie bijv. Hülsmann (2007, p. 41 en 364 e.v.).

42 Aangetekend zij dat een deel van de nationale wetgeving en het beleid teruggrijpt op Europees/internationaal beleid en wetgeving.

43 Institutioneel zijn er wel andere voorzieningen tot stand gebracht, zoals evaluatie- en erkenningscommissies die (ex ante) toetsen of gedragsinterventies (kunnen) werken, of opleidingsprogramma's aan de maat zijn en - zoals in ruime mate aanwezig in de gezondheidszorg - of nieuwe therapieën de beoogde effecten sorteren (vgl. Leeuw, 1992; voor een meer internationaal historisch overzicht van 'evidence-based policy making', Leeuw (in druk)).

44 Althans, als aan de opvattingen die navolgers zoals Rothbard en Friedman in de jaren tachtig publiek maakten, enige 'historische voorspelbaarheidskracht' toegedicht kan worden, waar het Von Mises' visie betrof.

45 Frissen (2007) roept op tot minder interventies en spreekt over het 'Museum voor Overbodig Beleid' (p. 74). Als hij bekend zou zijn met het werk van libertair economen, zoals Von Mises en navolgers, zou hij zien dat een deel van zijn filippica tegen de staat 
daar overeenkomsten mee vertoont. In zijn voetnoten komen verwijzingen naar deze traditie niet voor.

46 Vgl. Coleman (1990) die onderscheid maakt tussen (1) 'action formation'-mechanismen, (2) mechanismen die bepalend zijn voor (de wijze waarop) macrogegevenheden invloed hebben op individuele gedrag(skeuzen), en (3) mechanismen die ervoor zorgen dat aggregatie van uitkomsten van individueel gedrag (nieuwe) macrogegevenheden tot stand brengt.

47 Zie Axelrod (1984). Overigens wijzen Rooks et al (2000) erop dat dit mechanisme én een aanpalend ('shadow of the past') met elkaar samenhangen, zoals zij in een empirisch onderzoek onder managers laten zien. Ook neuro-economen zijn actief op dit gebied (vgl. Stuphorn, 2005).

${ }^{8}$ Er zijn overigens verschillende subtyperingen van cascades, zoals de informationele (zie het voorbeeld betreffende de manager van de Beatles) en het reputationele (waarbij mensen proberen aardig gevonden te worden door (grotere) groepen 'by saying things I think they will find agreeable', Farnsworth, 2007, p. 140 en 141). Het door psychologen onderzochte ingratiatieverschijnsel houdt er ook mee verband.

49 Farnsworth (2007, p. 137) citeert Bikhchandani et al. (1992), waarin een vergelijkbaar voorbeeld wordt gegeven ('(...) the authors of the business book who bought 50.000 copies in an attempt to get it onto the bestseller lists (...) where it then stayed'). In de briefwisseling tussen W.F. Hermans en Gerard Reve ('Verscheur deze brief! Ik vertel veel te veel', bezorgd door Nop Maas en Willem Otterspeer, De Bezige Bij \& Willem Frederik Hermans Instituut, 2008, p. 245) is de uitspraak van Reve te lezen dat hij 'in provinciale bladen [in de jaren zestig; FLL] onder een andere naam soms ingezonden stukken tegen mijzelf plaatste', dit om reclame voor hemzelf te maken.

50 Deze uitspraak wordt door Riedl (2006) toegeschreven aan Russel Long, 'tax legislator' in de VS.

51 Of onbekend is óf ze werken (en met welke neveneffecten).

52 Niet ondenkbaar is dat dit ook een probleem is bij de executie van strafrechtelijke en andere rechterlijke uitspraken. Van de Bunt (2000) sprak zo'n tien jaar geleden over het afvoerputje van het strafrecht. Het WODC verricht onderzoek naar deze problematiek. 53 http://www.sme.nl/instrumentenwijzer/index.html; http://instrumentenwijzer. arbeidtools.nl/wijzer.php http://www.szw-instrumentenplanner.nl/Default.aspx, http://www.kompas.novem.nl/ instrumentplanner/word/instrumentteksten.doc en http://www.hetkenniscentrum.nl/ bibliotheek/nieuws/2005/og/instrumentenwijzer_1017.html.

54 De term epigenetica wordt wel opgevat als het bestuderen van gen-

omgevingsinteracties, meer in het algemeen als de studie van de voortdurende interacties tussen genen en de omgeving, waardoor een individu zich ontwikkelt. De Kogel (2008) verwijst naar een 'beroemd epigenetisch voorbeeld op gedragsgebied, te weten het onderzoek aan ratten, waarbij opvoedingsaspecten, in dit geval de mate van likken en 
andere lichamelijke verzorging door de moeder, bij de jongen de werking van genen die de ontwikkeling van het stressysteem reguleren, beïnvloedde (Weaver et al., 2004). Bij jonge ratjes die veel werden gepoetst, werden bepaalde genen die van belang zijn voor de ontwikkeling van het stresssysteem "voluit" aangeschakeld. Hierdoor maakten de ratten minder stresshormonen aan, en waren ze als volwassenen minder angstig en minder gevoelig voor stress. Bij de kleintjes die in mindere mate lichaamsverzorging van hun moeder kregen, bleven deze genen in de uitstand. Die jongen waren als volwassenen schrikachtiger en vatbaarder voor stress.'

55 Klein Haarhuis en Niemijer (2008) laten zien dat deze typering is 'ontleend aan 59 voldoende valide en betrouwbaar bevonden wetsevaluaties. Of dit beeld representatief is voor het geheel aan wetgeving is onzeker'. De onderzoekers wijzen ook op een zestal institutionele mechanismen, zoals 'zelfsturing' en het 'nemen van de regierol', maar naar mijn oordeel is bij elk van deze 'institutionele mechanismen' een of meer gedragsmechanismen onderliggend.

56 Klein Haarhuis en Niemeijer (2008, p. 15 en 17): 'Zeker 60\% van de wetsevaluaties is geheel of gedeeltelijk een doelbereikingsevaluatie. De vraag in welke mate bepaalde wettelijke doelstellingen zijn bereikt staat centraal. Bijna tweederde van deze doelbereikingsevaluaties bevat tevens een gedeeltelijke reconstructie van de uitvoering en/of van andere processen in de praktijk, zoals attitude- en gedragsveranderingen bij de doelgroep. Hier is dus sprake van een combinatie van doelbereikings- en (partiële) procesevaluatie. Eéntiende van de rapporten bevat een zuivere procesevaluatie. (...) De doelbereiking blijkt middelmatig wanneer burgers of bedrijven rechtstreeks met wetgeving worden aangestuurd. Wanneer naast burgers of bedrijven óók uitvoerders worden aangestuurd, lijkt de doelbereiking van wetten geringer (...) Onder de wetsevaluaties bevinden zich geen effectiviteitsonderzoeken in strikte zin.' 57 Op grond van de Maryland Scientific Methods Scale (vgl. Leeuw, 2005). 58 Werk van Wippler en Lindenberg uit de jaren 80 van de vorige eeuw vroeg in de sociologie al aandacht hier voor (vgl. Arts, Lindenberg en Wippler (1976) en Wippler (1978). Aandacht voor overbruggings- en transformatieregels om de relaties tussen micro- en macroverschijnselen te onderzoeken, is éen van de rode lijnen in deze sociologiebeoefening. Uit eigen ervaring weet ik hoe vruchtbaar deze aanpak is. 59 Ik richt me hier vooral op beleid en bestuur en niet op het recht. Deels gaat het om dezelfde mechanismen overigens. Zie Walter K. Olson, The Litigation Explosion (New York: Dutton, 1991).

6o Schrijver dezes heeft samen met collega's uit verschillende universiteiten geprobeerd om, toen een paar jaar geleden de fundamentele herbezinning van het burgerlijk procesrecht door een gezaghebbende commissie aan de orde werd gesteld en er ook met voorstellen werd gekomen hoe een en ander efficiënter en effectiever te laten verlopen, de werking van deze voorstellen aan een gedragswetenschappelijke analyse te onderwerpen (vgl. Barendrecht et al., 2004). Vragen waren onder andere wat we uit deze 
disciplines (waaronder de economie) al wisten over de rol en werking van de taakopvatting van de rechter bij processen, de kosten en baten van preprocessuele schikkingscomparities en over de rol van de rechter als 'manager/regisseur' van zaaksbehandelingen.

61 Vgl. UM-collega Ton Broeders, die zich met de forensica en het forensisch onderzoek aan de UM bezighoudt en oproept dat in de juridische opleidingen meer tijd besteed moet worden aan statistiek. Loonen (2008, p. 160) schreef tegen lekenrechtspraak te zijn, omdat er al zoveel lekenrechtspraak is: 'rechters doen namelijk uitspraken op basis van biomedisch bewijsmateriaal of opvattingen over de gezondheidstoestand van personen, zonder op dat terrein deskundig te zijn. Het betreft dus een lekenoordeel (...).' Gelukkig zijn er ook, en groeiend in aantal, uitstekende aanzetten, waarbij de werking van juridische arrangementen met een flinke keur aan gedragswetenschappelijke kennis wordt geëvalueerd, zoals Van Bijnen (2005) in zijn studie van de werking van het contractenrecht liet zien of zoals Rachlinski doet (2005). Deze auteur maakt duidelijk hoe belangrijk kennis over gedragsmechanismen is bij het begrijpen wat er gebeurt als, op samenlevingsniveau, 'legal regimes crash'. Meer aandacht binnen juridische opleidingen voor het evalueren van de werking van wetten en (rechts)regels en andere juridische constructies is ook nodig (vgl. Leeuw \& De Jongste, 2006).

62 Neuro-economen zijn een van de uitzonderingen. Zie het hoofdstuk over 'social neuroscience' van De Kogel (2008), maar ook Egas en Riedl (2008).

63 Met een verwijzing naar Ultee (1977, p. 156) kan gesproken worden van een theorie met overschotgehalte. Daarvan is sprake als 'een theorie (tot ontwikkeling wordt gebracht) die een aantal aanvankelijk los van elkaar staande hypothesen omvat'.

64 Pawson (2006) werkt in de traditie van de 'realist evaluation', waarbij belangrijke vertrekpunten zijn dat 'policies are theories', het, om de werking van interventies te begrijpen, nodig is kennis te hebben over de context(en) waarbinnen deze interventies opereren, én van (gedrags) mechanismen, en waarbij niet alleen resultaten uit experimentele of quasi-experimentele studies gebruikt worden (zoals door aanhangers van de Campbell Collaboration wordt geëist), maar méér typen evaluatieonderzoek gebruikt worden (vgl. Leeuw, 2005; Kleemans et al., 2007; Van der Knaap et al., 2008). 65 Hij ontleent deze term aan Lawson (1997). 

